\title{
LA RIVOLUZIONE MACCHIATA THE STAINED REVOLUTION
}

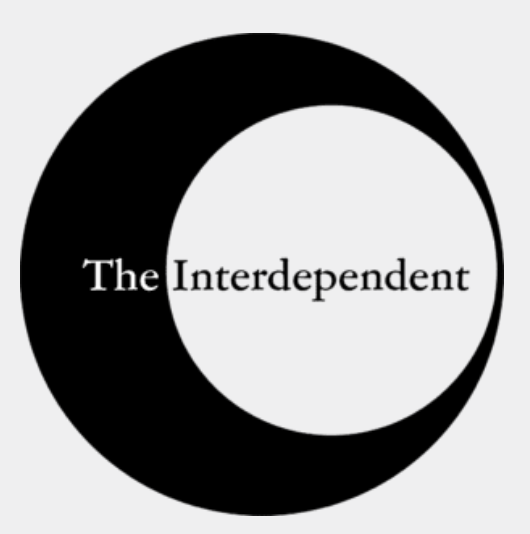

Sasha Souillard I souillard.sasha@gmail.com

B.A. Global Liberal Studies, 2020 | New York University, New York Commercial Operations Analyst | ViacomCBS, New York

https://doi.org/10.33682/nv4g-se2u

\section{A B S T R ACT}

Although graffiti gained popularity through the expansion of American pop culture, its origins are greatly embedded in Italian culture and history. Not only does the word graffiti come from the Italian word "graffiato" or "scratched "off", but some of the world's first graffiti was found in Pompeii's ruins. Over the last few years, Italy has been governed by right-wing coalitions that have implemented fascist practices once used by Mussolini. Given that there is little space for leftist ideas to emerge in the public space, Italians have used graffiti as a form of political activism and protest. Conversations surrounding fascism, racism, women's rights, immigration and the LGTBQ community have arisen within graffiti, allowing outsiders to better understand Italians' takes on these issues. This study investigates Italy's sociopolitical climate through graffiti as a form of art, and also sheds light on how graffiti provokes its audience. The graffiti found in Florence, Bologna, and Naples proves to be linguistically complex, and provokes observers both through heightened language and visuals. This study suggests that the majority of Italian sociopolitical graffiti belongs to students who are unable to take part in democracy based on their age or legal status. While often deemed a vandalistic act, graffiti has allowed Italian individuals to protest what is unjust, and make themselves heard in a society where their voices are being suffocated by right-wing political parties and their media.

\section{KEY WORDS}

Graffiti; Fascism; Anti-Fa; Street Art; Graffiti Tags; Mussolini; Italy; Salvini; Political Activism Rhetoric; Immigration; Racism; Protest; Right-wing Politics; Left-wing 

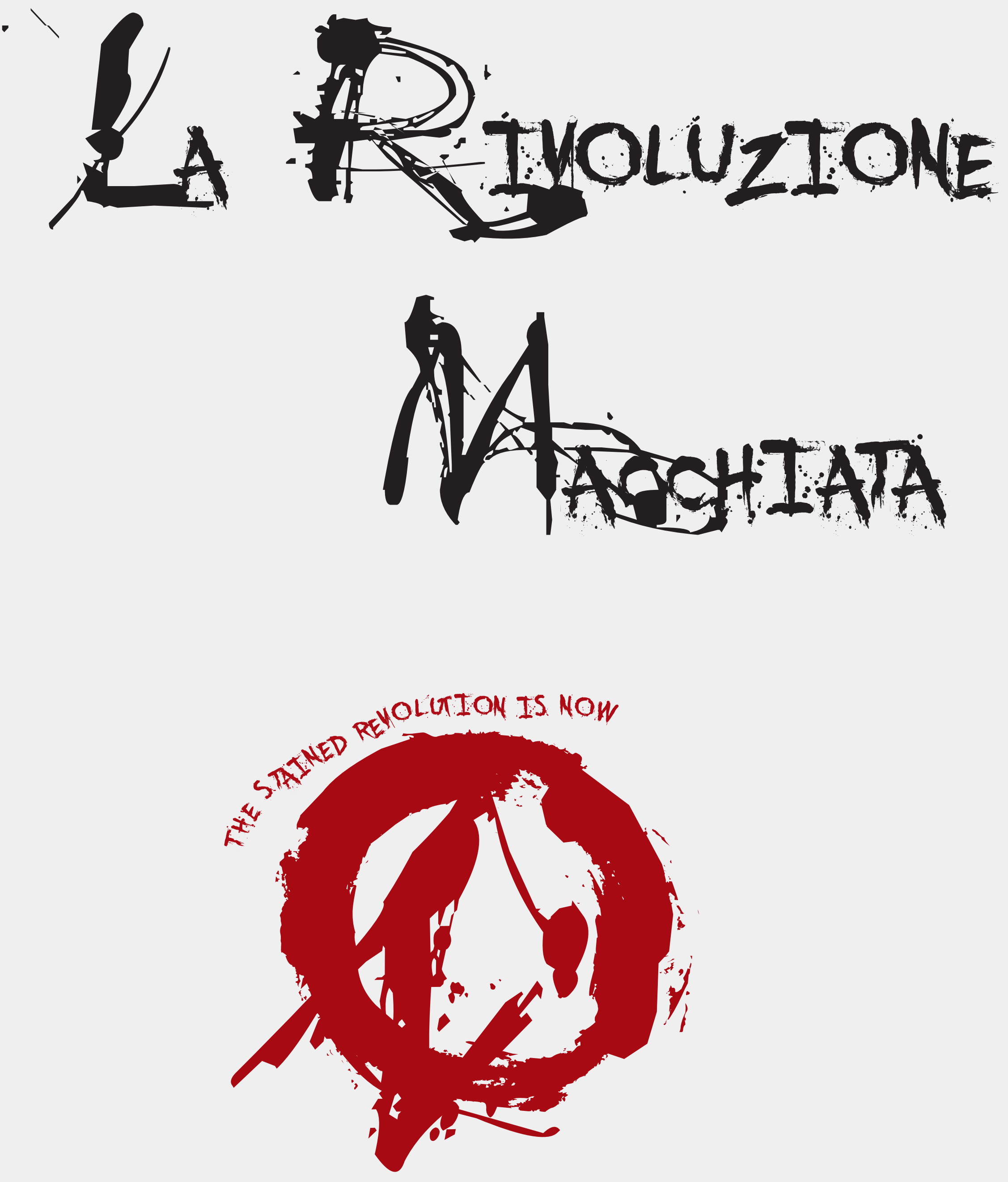
Graffiti is undeniably tied to Italian culture given that the word itself stems from the Italian word "graffiato" or "scratched off." 1 From as early as the 6th century, "graffiti" was the term used to describe the inscriptions and figure drawings found on ancient Italian walls. ${ }^{2}$

Many disciplines continue to debate graffiti's integrity as art, given its alleged vandalistic characteristics and its tendency to disrupt and destroy public and private property. ${ }^{3}$ However, from very early on, Italian cities have vouched for the societal acceptance of graffiti.

Some of the world's oldest graffiti, found in Roman Catacombs and Pompeii, ${ }^{4}$ transcend public art. These drawings functioned to commemorate individuals, express acclamations or simple satire, or to record so- $^{-}$ ciological and cultural life. ${ }^{5}$ Today, these functions still exist, allowing graffiti to materialize the thoughts that run through the minds of the Italian people.

Pro-graffiti graffiti found in present-day Italy suggests that even "the smallest phrases written on walls create large works of art." In addition to advertising their stance on the art medium, pro-graffiti artists have also begun partaking in transformation-a popular phenomenon that allows artists to manipulate the graffiti of others in a way that denotes its original meaningas a form of promoting art's power to move people.

Transformation is seen in a writing that reads "L'ARTE NON VINCE" or "ART DOES NOT WIN." In spite of this negative narrative surrounding art, this graffiti was later manipulated to fit a different narrative. After its initial production, a separate graffiti artist crossedout "DOES NOT WIN" and inserted a caricature spray painting over the original writing. By using graffiti as a weapon against itself, the new artist reiterates that "ART DOES WIN."

Rather than being a product, graffiti turns into a production. ${ }^{6}$ Author and visual culture scholar David Fieni describes how graffiti's meaning changes as a result of both manipulation, and its temporal and histoical conditions.

Graffiti is created even when it is well aware of its future de-struction. ${ }^{7}$ Its eventual demolition is not interpreted as repression. ${ }^{8}$ Rather, it uses its ephemerality in order to strategically spread momentous, and provocative messages. ${ }^{9}$ In the time that it exists, it must carefully target the people who it is intended to reach.

Italian graffiti surpasses the initial conversation of whether graffiti is classified as art or not. Rather, it encourages people to "REBEL EVEN IF ITS JUST THROUGH ART." But how and why does one rebel through graffiti? And most importantly, what is there to rebel against? Over the course of the last decade, Italy's right-wing politics have polarized the country, and have silenced the voices of the left. Sociopolitical graffiti has begun dominating the streets

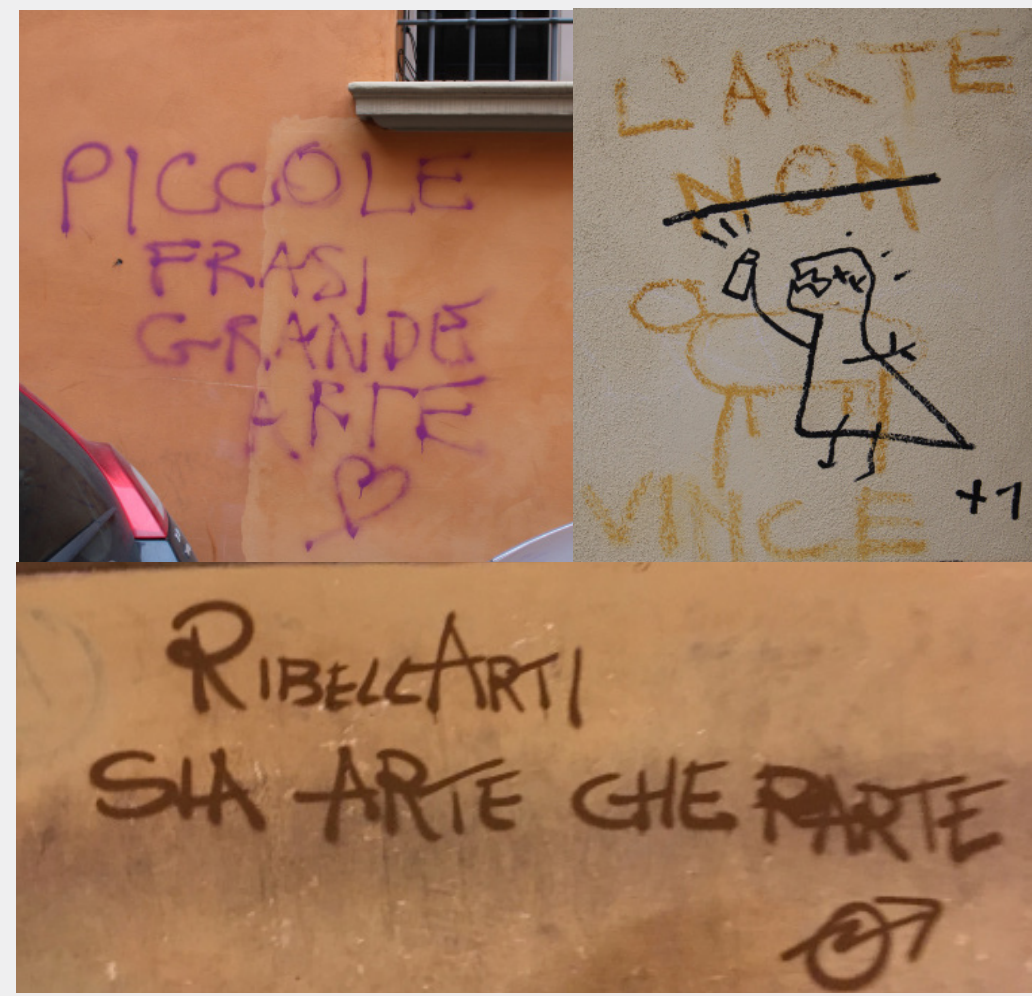

AN

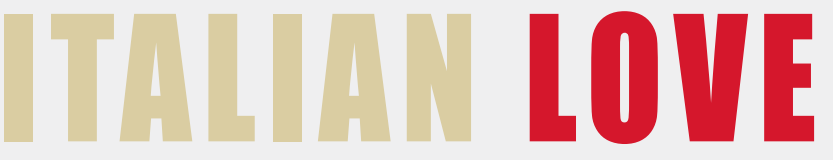

of Italian cities, making public discourses about re-emerging fascist ideas, women's rights movements, immigration, racism, and the discrimination of other minority groups accessible. Regardless of age, skill, socioeconomic bracket, and citizenship, ${ }^{10}$ individuals

While walls are meant to separate and keep others out, Italian walls are rather inviting. ${ }^{11}$ The graffitistained walls aim to unify communities by voicing shared reflections and attitudes, ultimately becoming a valid gauge of their moral and cultural values. ${ }^{12}$ Instead of creating physical boundaries to ensure security, the walls serve to break social boundaries. ${ }^{13}$

La Rivoluzione Macchiata aims to showcase graffiti's singular, but diverse role in serving as a response to the Italian government. It doubles as both an outlet for the left, and an outlet that normalizes graffiti as an effective, powerful, and valid form of politi-cal activism. In analyzing and tracing the origins of present-day Italian graffiti, the sociopolitical history of the country also unfolds and becomes context for the sociopolitical climate of Italy today. 


\section{THIS IS THE LIFE, LONG REBELLION...}

\section{THE INTERTWINED HISTORY OF ITALIAN FASCISM AND GRAFFITI}

The resurgence of Italian sociopolitical graffiti is undeniably intertwined with the rise and survival of fascist regimes. Mussolini manipulated public art and architecture not only to beautify the nation, but to bring its people together through their shared respect, loyalty, and admiration for him. ${ }^{14}$

In hopes of cultivating fear and expanding his totalitarian nation, Mussolini had paintings of himself dispersed throughout cities..$^{15}$ Soon, Mussolini's supporters began creating similar works of art in order to promote fascism. ${ }^{16}$ This propaganda took shape as graffiti and murals accompanied by slogans such as "Credere, Obbedire, Combattere!" and "Mussolini sempre guisto!" which respectively mean "Believe, Obey and Combat!" and "Mussolini is always right!" ${ }^{17}$ Graffiti artists took inspiration from his latest speeches and would spray paint his quotes all over city walls. ${ }^{18}$

After the supposed end of fascism, the Cristian Democrats, Communist and Socialists all fought for power. ${ }^{19}$ Given that the country was politically split and unstable, graffiti supporting these new governments emerged. This graffiti typically consisted of logos and symbols which are more commonly known as "tags."20

Amongst communist, anarchist, and socialist tags, another tag emerged. Characterized by a zig-zag arrow that cuts through a circle, the squatters tag has been adopted by anti-fascists and redefined as a symbol of the Anti-fa movement. This movement is characterized by the collective dislike of fascism, regardless of what type of government individuals support. ${ }^{21}$

By putting their political associations aside, communists, socialists and anarchists taking part in the Anti-fa movement have allowed the tag to flourish with a separate identity. These tags are still seen throughout the streets of politically vocal, Italian cities.
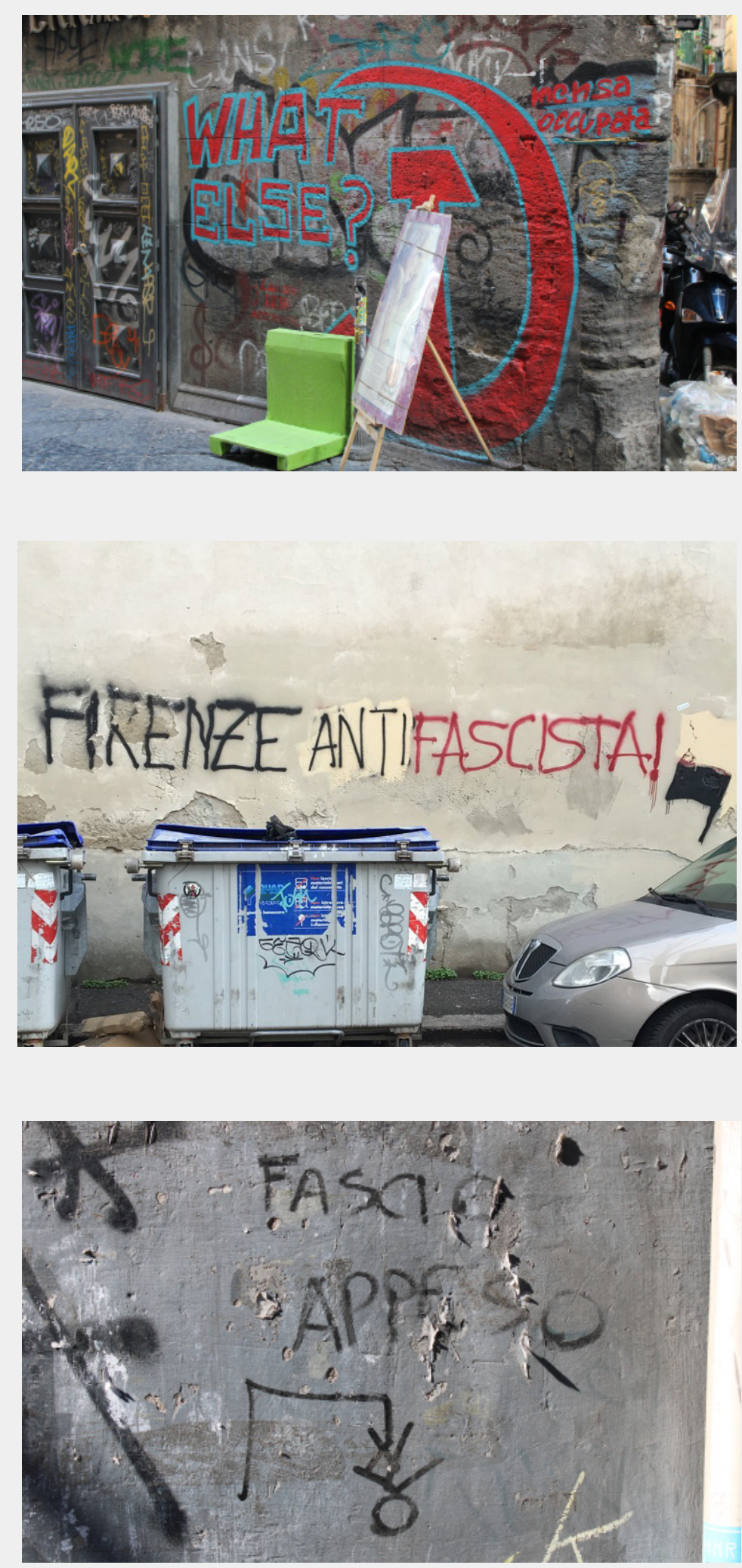

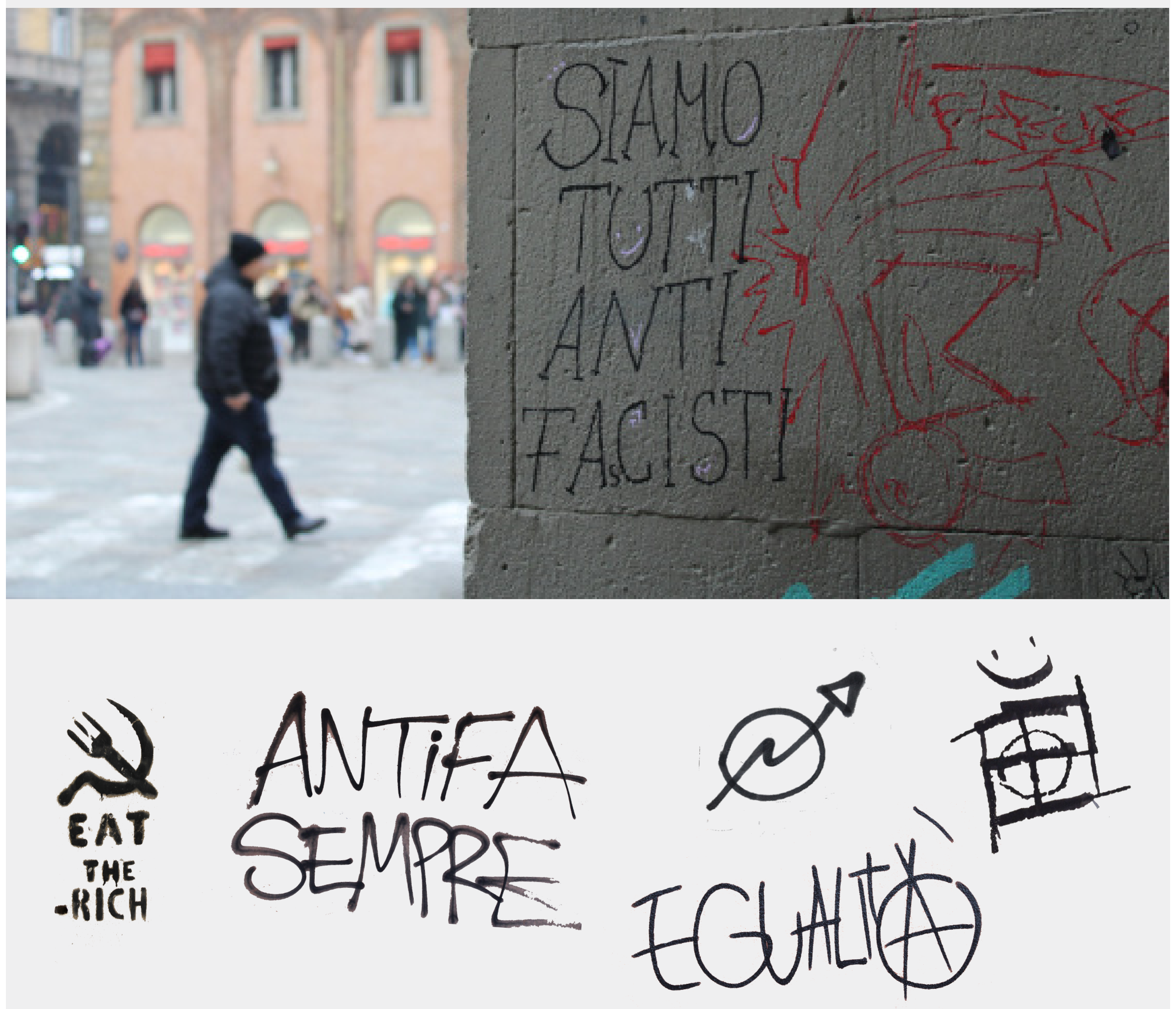

Anti-fascist graffiti has evolved over the years and has begun to attach phrases and slogans to tags. Most commonly, graffiti artists will give their city an anti-fascist identity by printing the word "ANTIFA" after the city name. A red and/or black flag has also emereged as a new Anti-fa sysmbol and is attached to existing anti-fascist graffiti. This symbol also inhabits cities through stickers that are plastered all over street signs, walls, posters and more.

Additional anti-fascist graffiti reads "WE ARE ALL ANTI-FASCISTS", "ALWAYS ANTIFA", and variations of the two. More aggressive anti-fascist graffiti has materialized as well; it reads"FASCISTS ARE SHIT" and "HANG THE FASCISTS" with a stick figure man being hung underneath it.While

many individuals create their own graffiti, the practice of suppressing and transforming existing fascist graffiti is also very common.Examples of transformation include painting over fascist logos, adapting them to render them harmless, or politicizing them in an alternative way ${ }^{22}$ Throughout Italy, graffiti artists have added the prefix "anti" in front of fascist slogans, or drawn boxes around swastikas, accompanied by smiley faces.

Through different graffiti practices, Italians have used public walls to create a collective, anti-fascist identity. Graffiti gives people the means to riot, rebel, and never stop fighting against fascism. resurgence of Italian sociopolitical graffiti is undeniably intertwined with the rise and survival of fascist regimes. 


\section{GRA.TiTII:}

\section{A TESTIMONY TO \\ RE O C C UR IN G FASCIST PRACTICES}

Additional anti-fascist graffiti has emerged throughout Italy in protest of the right-wing government currently in place. In order to understand the general emphasis graffiti places on fascism, it is important to trace the history of Italian fascism and how it has seeped into present-day politics.

Also known as Il Duce (The Leader), Mussolini rose to power during the early 1920 s when Italy was perceived as a weak nation. In hopes of restoring Italy's former prestige, Mussolini used fascist practices to establish and fortify a collective Italian identity and a state that had common interests and goals. ${ }^{23}$

Like many other totalitarian rulers, Mussolini's fascism was defined by emphasizing radical nationalism and by manipulating the state through sociopolitical propaganda. ${ }^{24}$

Although Mussolini was removed from power by the Allied Powers and the Gran Consiglio del Fascismo in hopes of ending fascism, ${ }^{25}$ the ideologies that he created and implemented over the course of
20 years lived on through other channels. ${ }^{26}$

In 1943, a group of Mussolini's fascist soldiers formed the Movimento Sociale Italiano, a new right-wing political party. ${ }^{27}$ Although the party lived under the radar for 30 years, it reemerged into the public space as a neo-fascist groupwith a fascist ideology that promotes ultranationalism, racial supremacy, authoritarianism, nativism, and xenophobia. ${ }^{28}$

Unfortunately, many of the politics that once existed during and after Mussolini's regime have carried into the 21 st century. Italy's most recent governments have been predominately rightwing, with coalitions forming between the Lega Nord, Forza Italia, and Alleanza Nazionale. ${ }^{29}$

Similar to Mussolini's interests, these political parties share the common goal of unifying the country by creating one common Italian identity, ${ }^{30}$ leaving very little room for diversity and sociopolital differentiation. Rather than trying to bring Italian people together by eliminating regionalism, these parties have repositioned the divide. $^{31}$

The Lega Nord is one of the most influential parties within the coalition given that it is characterized by its "ability to interpret, from a new perspective, political issues based on the traditional conflicts within the country." ${ }^{2}$ This party uses the anti-immigrant ideology that the Movimento Sociale Italiano led with in order to pin Italians against the "other", rather than against themselves during a politically split period of time.

These sentiments are easy to reinstate within the public because they never dissipated. These neo-fascist ideas lived on through the Moviemento Sociale Italiano which never actually
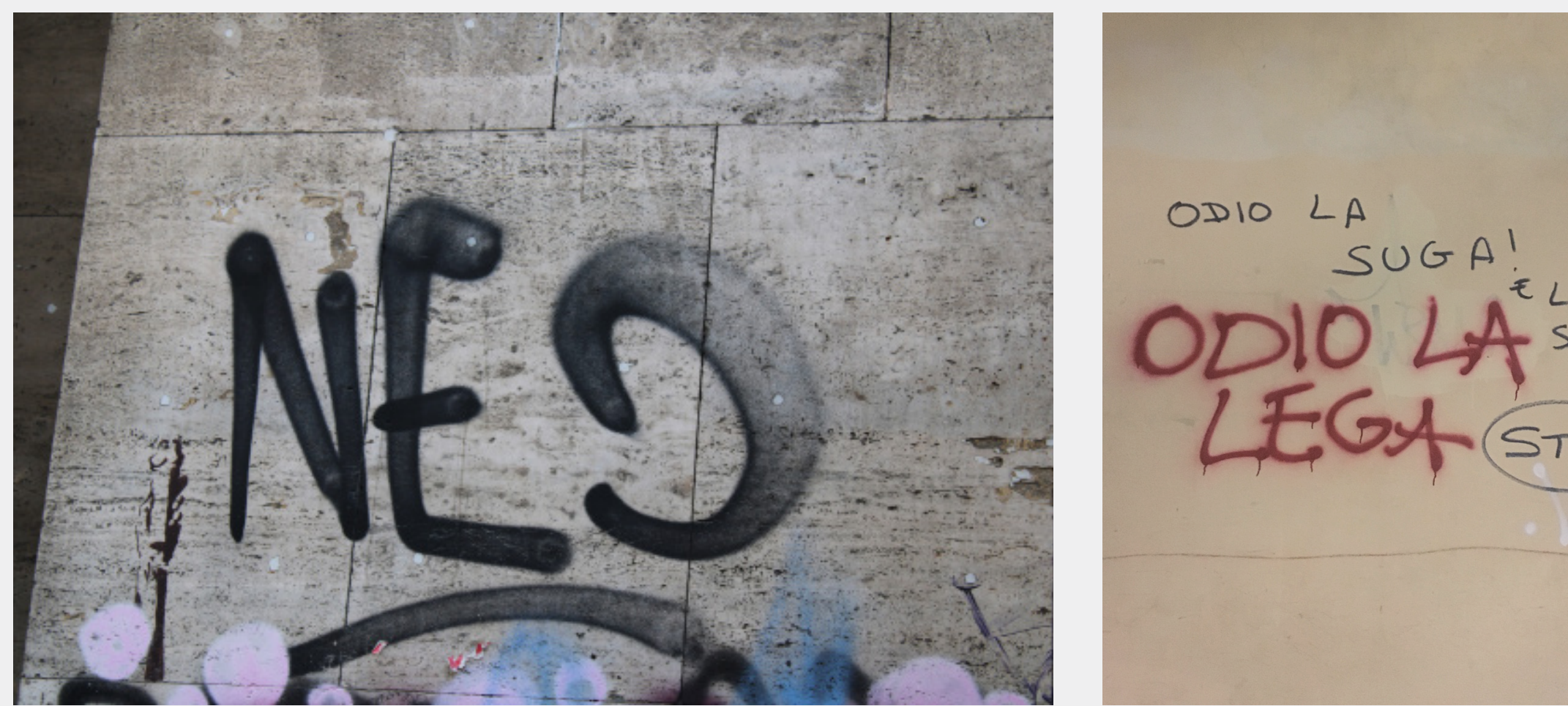
dissolved. ${ }^{33}$ Instead, the party rebranded under the name Allenaza Nazionale in hope of distancing itself from its past radical politics. ${ }^{34}$

Forza Italia is the last party that works in coalition with the Lega Nord and Alleanza Nazionale. This right-wing party has adopted many of Alleanza Nazionale's nativist and xenophobic sentiments given that it originally derived from Alleanza Nazionale, and was then revived as an independent party years later. ${ }^{35}$

Silvio Berlusconi, one of the longest serving postwar Prime Ministers, was one of the main founders of Forza Italia Throughout his nine years in office, he ensured that his neo-fascist ideas spread throughout the nation and through his political party. ${ }^{36}$

Similar to Mussolini, Berlusconi's political ideology surrounding Italy's sociopolitical unification transcended his terms, and has influenced other prime ministers that succeeded him. Such prime ministers include Matteo Salvini and Giuseppe Conte.

Throughout Italian streets, a plethora of graffiti exists denot-

ing the return of Mussolini's fascist practices, as well as the existence of neo-fascism surviv-

ing through contemporary political leaders and their respective parties.

"I HATE THE LEAGUE" can be found written on walls, in addition to "SALVINI IS SHIT", "NAPOLI HATES YOU SAL" VINI", and "MUSSOLINI SON OF A BITCH." Lastly, the word "NEO" is also heavily present in Italian sociopolitical graffiti, referencing neo-fascism.

While fascism was deemed dead after Mussolini's removal from power, it continues to live on through right-wing parties. Italians have taken their anger and resentment toward the government to the streets as a way to be heard and fight back. When there is nowhere to turn, graffiti always presents itself as an acceessible outlet.
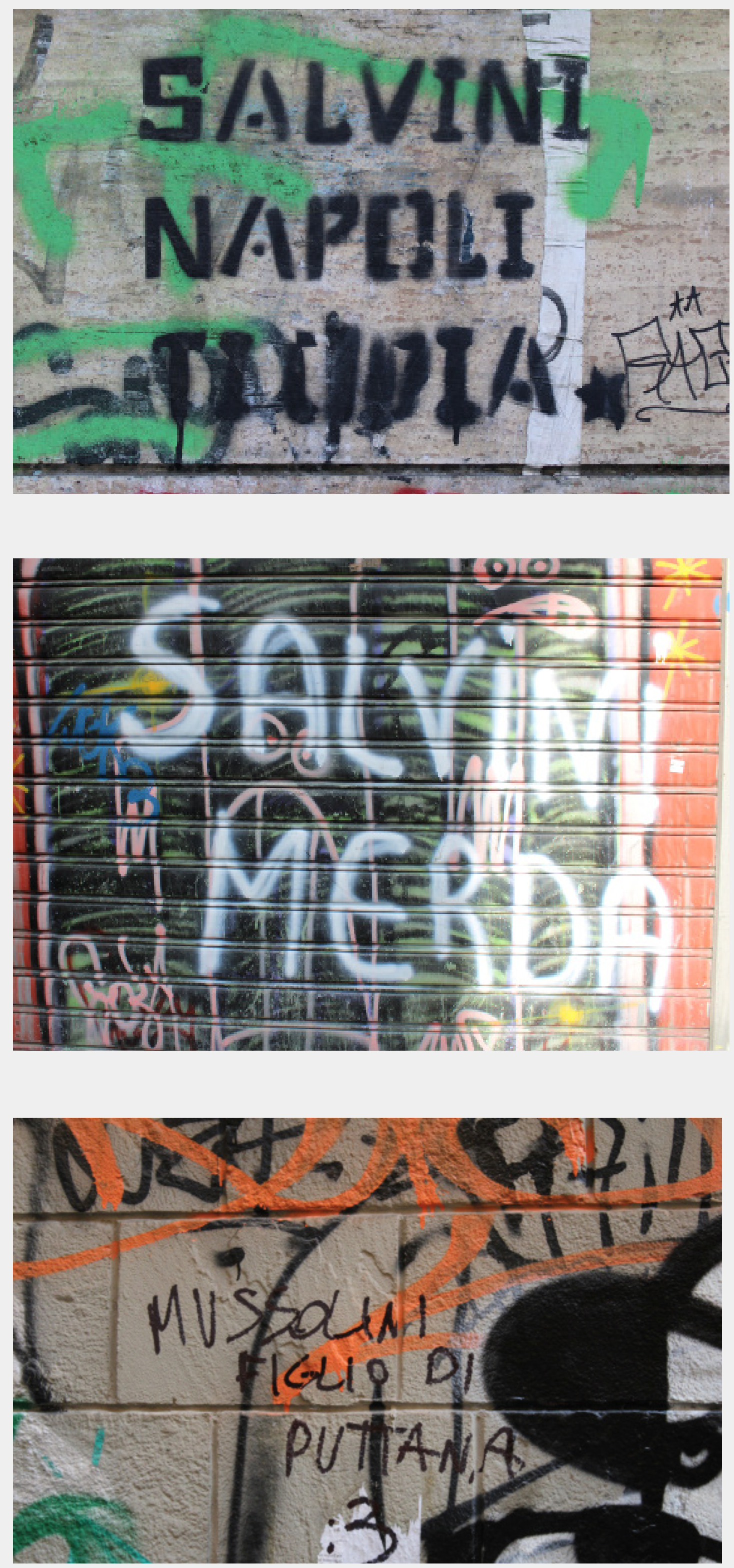


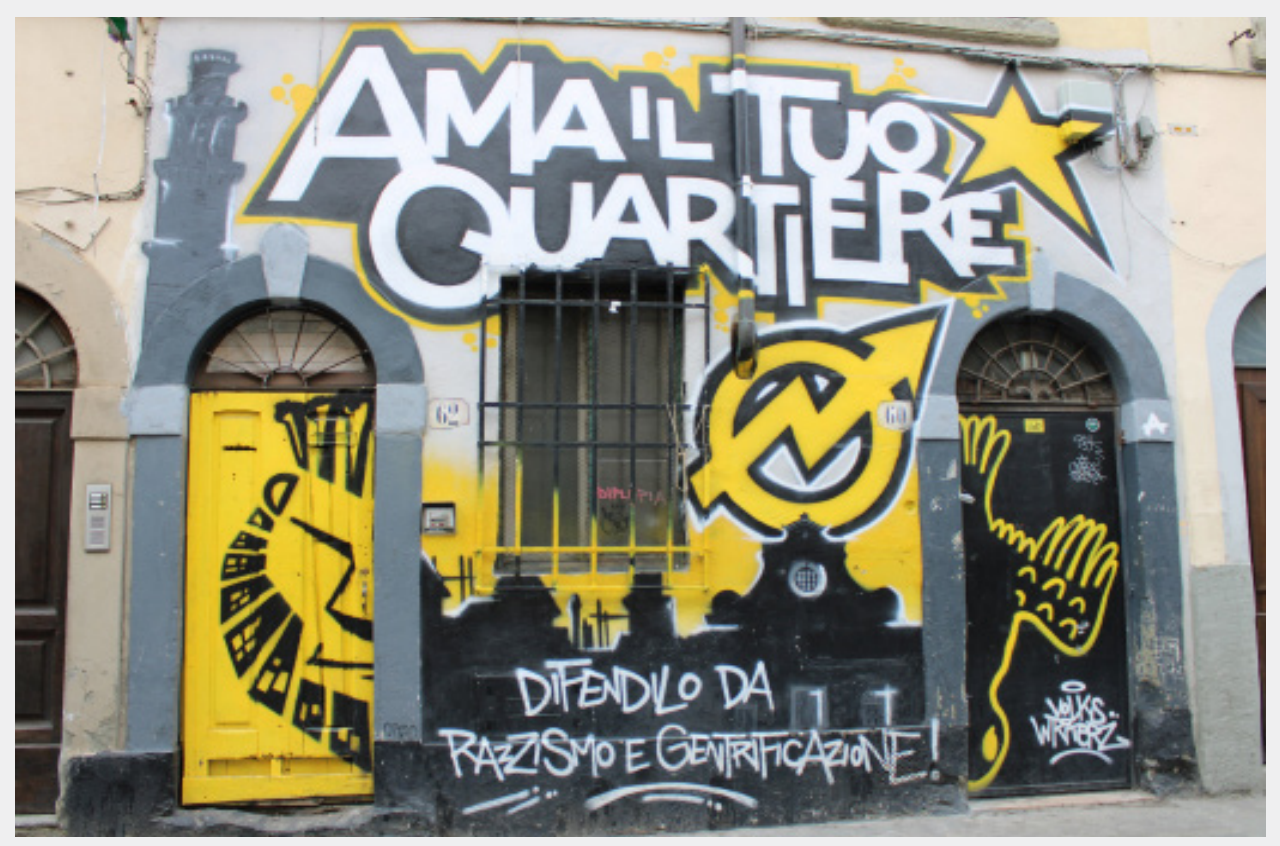

\section{SPLIT BETWEEN THE WALLS: SAYYHG HO TO RACISM}

Social and political tension between Italian northerners and southerners can be traced back to the 19th century when Cesare Lobroso, an Italian criminologist and anthropologist, studied the evolutionary theories of racial development. ${ }^{37}$

In tracing the genealogy of criminals, Lombroso suggested that southerners were an inferior Italian breed. ${ }^{38}$ He concluded that southerners were "less capable of progress in the political and social organization, [. . . ] were of question-able value," and lacked mental ability because they descended from African blood. ${ }^{39}$ These "scientific" racist concepts resulted in the normalization of stereotypes, and encouraged the division between the north and south of Italy. ${ }^{40}$

This divide, determined by race and color, continued throughout the 20th century and was enhanced by the Movimento Sociale party. ${ }^{41}$ Rather than deeming southerners as the internal enemies, the Movimento Sociale repositioned this divide and began targeting immigrants. ${ }^{42}$ Through the 1990 s, African, Middle Eastern, and Asia immigrants became the targets of racial violence and discrimination of this party ${ }^{43}$ in hopes of instilling fear and exaggerating their presence in Italy. ${ }^{44}$

Researcher Daniele Albertazzi from Birmingham University explains that the nativism which currently exists in Italy is as a result of Matteo Salvini's national focus and protectionist motifs. ${ }^{45}$ Salvini encouraged the idea of preserving an authentically Italian state by suggesting that non-Italians would become detrimental to the country. ${ }^{46}$

Politicians such as Salvini and Berlusconi are responsible for the anti-immigrant rhetoric that exists in the public sphere. ${ }^{47}$ Like the Movimento Sociale, these figures and their parties create unprecedented fear in hopes of controlling the public perception of non-Italians. In fact, the majority of national radio stations, television networks, and newspapers are owned by right-wing political parties, and individuals like Berlusconi. ${ }^{48}$ The rightwing is able to control the sociopolitical narrative of the nation and curate it in a way that enhances their ideology.
The negative discourse surrounding immigration in the media has created a climate of intolerance and harassment. This discourse has transcended traditional outlets such as Radio Padania Libera and Telepandia TV, and has also materialized as graffiti.

After its re-emergence in the 1990s the Movimento Sociale began sponsoring racist, and anti-immigrant graffiti. ${ }^{49}$ Nearly 20 years later, this anti-immigrant graffiti has specified into anti-Islamic graffiti, and is found plastered on mosques and other centers of Islamic expression. ${ }^{50}$

In order to combat these neo-fascist and racist ideals, leftist graffiti such as "FERMIAMO LA VIOLENZA RAZZISTA", or "LETS STOP RACIST VIOLENCE" has emerged.

Although this Florentine graffiti speaks to the protection of all immigrants, it particularly channels and memorializes the events that took place in Florence. On March 5th, 2018, Senegalese immigrant and trader Idy Diene was shot three times on the Ponte Amerigo Vespucci. ${ }^{51}$ Although shooter Roberto Pirrone declared that the shooting was not racially or politically motivated, he also expressed that he aimed the loaded gun at multiple individuals before deciding on his victim. ${ }^{52}$ The police confirmed that there was no racist intent in the perpetrated murder which generated a lot of controversy. ${ }^{53}$

Additional graffiti expresses the need to "LOVE YOUR NEIGHBORHOOD AND DEFEND IT AGAINST RACISM AND GENTRIFICATION!" This graffiti is accompanied by sketches of Florence marked with anti-fascist symbols.

Governments manipulate rhetoric in a way to control their states, and ultimately, their people. While this rhetoric transcends national platforms and becomes visible on city streets, graffiti combating these ideals has also appeared as a response. While the left may have very few national resources to their disposal, it is attempting to take graffiti back from the right, and use it as their own platform.

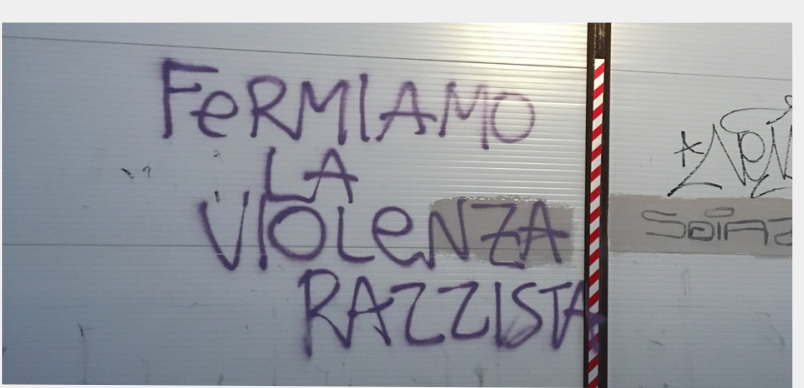



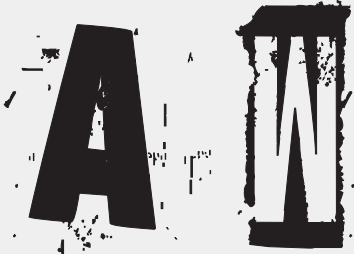
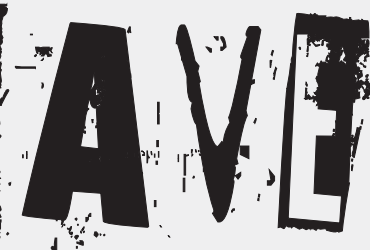
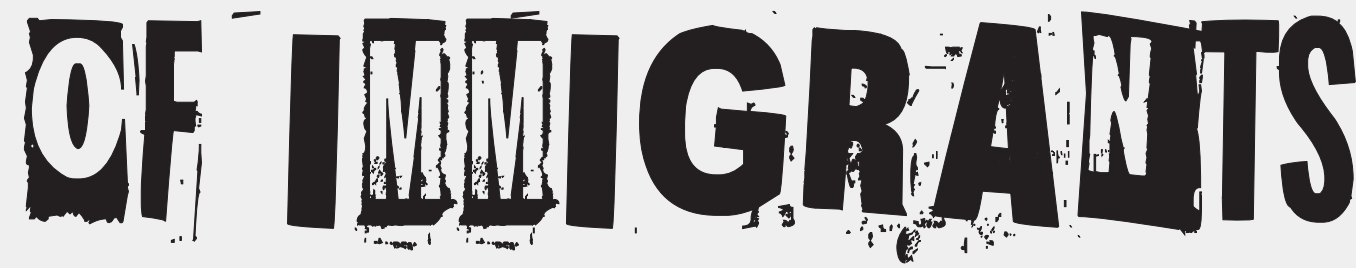

\section{HOW DISCOURSE IS PLAYED OUT ON THE STREETS}

and immigration. The majority of this graf-

fiti is leftist and encourages the protection of refugees and asylum seekers.

Immigration is arguably the largest economic,social, and political problem burdening Italy. ${ }^{54}$ In 2010 over 3 million immigrants resided in Italy, with over $73 \%$ of them being non-EU residents. ${ }^{55}$ Eleven years later, it is estimated that the immigrant population has almost doubled as a result of worsening of conditions in the Global South. ${ }^{56}$

Italy is one of the European countries most affected by the immigrant crisis because of its proximity to African, Asian, and Middle Eastern countries experiencing political turmoil. Lampedusa, an island right off of southern Italy, has become the prime transit point for immigrants given that it is the most accessible European territory by boat. ${ }^{57}$ Tens of thousands of immigrants have crossed the Mediterranean in hopes of arriving in Lampedusa, and ultimately establishing a better life for themselves. ${ }^{58}$

Although Lampedusa is relatively close to Libya, Tunisia, and other countries responsible for the influx of immigrants, the journey across seas is characterized by incredibly poor conditions. Not only is it still a long journey, but the boats are overcrowded which creates hazardous sanitary conditions. ${ }^{59}$ The containment of sicknesses and rationing or resources becomes extremely challenging when boats have upwards of 2,000 passengers. ${ }^{60}$ It goes without saying that many individuals lose their lives in making this journey overseas. ${ }^{61}$

Immigrants face dehumanizing conditions during this experience, which in turn becomes a way for Italians to justify their perception of asylum seekers as inferior. They express apathy towards the conditions immigrants face both on this journey and in their home country. However, this apathy has grown and turned into resentment. ${ }^{62}$

A mural found in Florence tries to human-
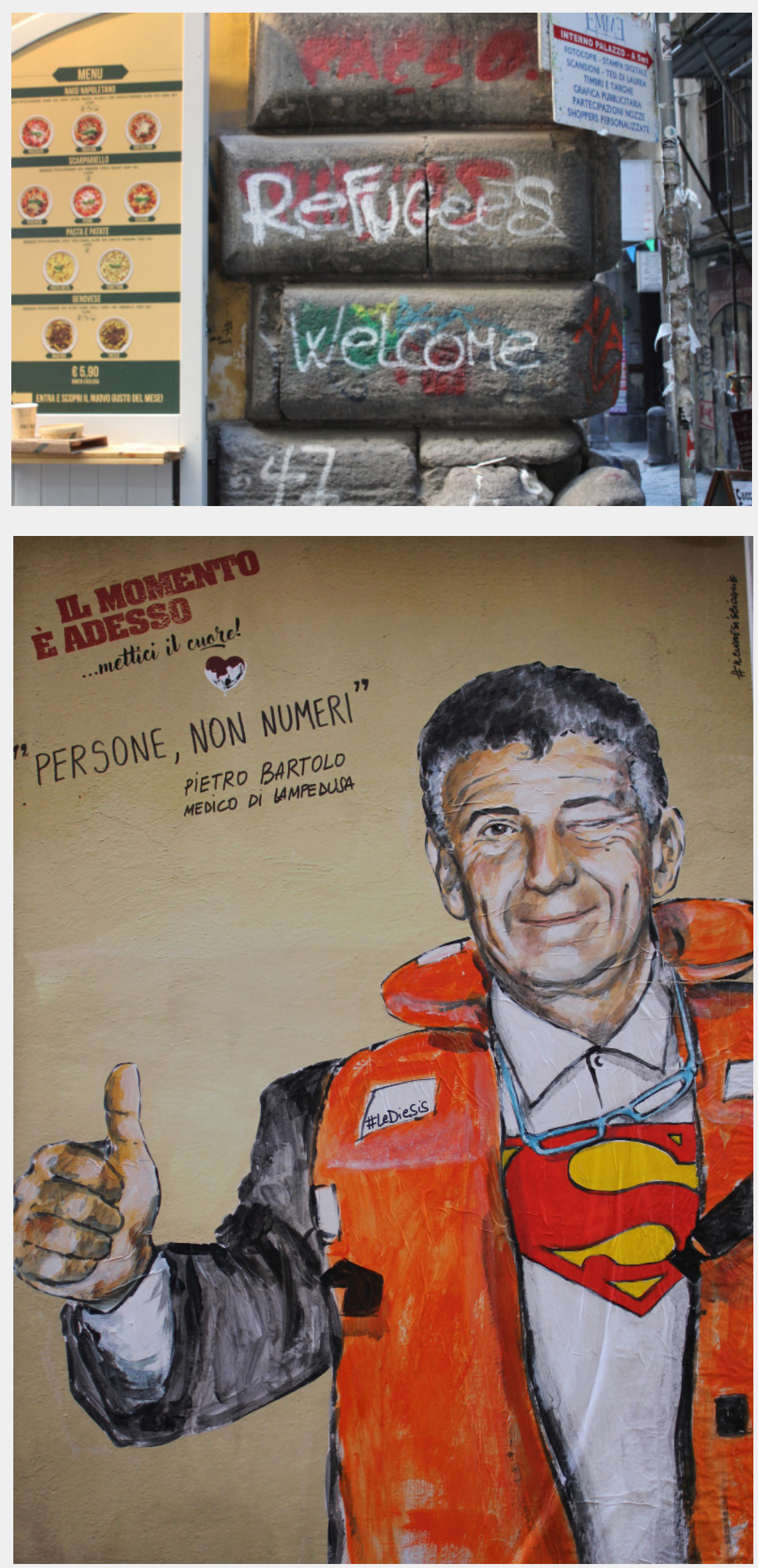
ize asylum seekers arriving in Lampedusa by declaring that they are "people, not numbers." Immigrants put their faith in Lampedusa's doctors, police, and legal representatives upon arrival in order to receive the aid they need. Hence, it is important that this graffiti repositions the attitude of first responders from apathetic to compassionate as well. If Italians do not approach these situations with humanity, they are putting the lives of asylum seekers at risk once again. For this reason, this graffiti depicts any individual who provides relief as superman-a hero.

Additional graffiti reiterates that refugees should be welcomed into the country regardless of their legal status and that deportations should be banned. Along similar lines, the conversation surrounding the elimination of borders becomes multi-layered as it interests both immigrants and the state.

Immigrants are only assigned refugee status once they apply and are granted asylum. By law, immigrants are forced to declare asylum in the country of their arrival. ${ }^{63}$ Yet, the immigrants that are arriving in Lampedusa and other Italian ports of entry do not want to declare asylum in Italy. ${ }^{64}$

Immigrants enter Italy in hopes of traveling throughout Europe to find their friends and family who have been granted asylum in other countries with more resources. By banning borders, immigrants would be able to travel throughout Europe without fear of being detained by border

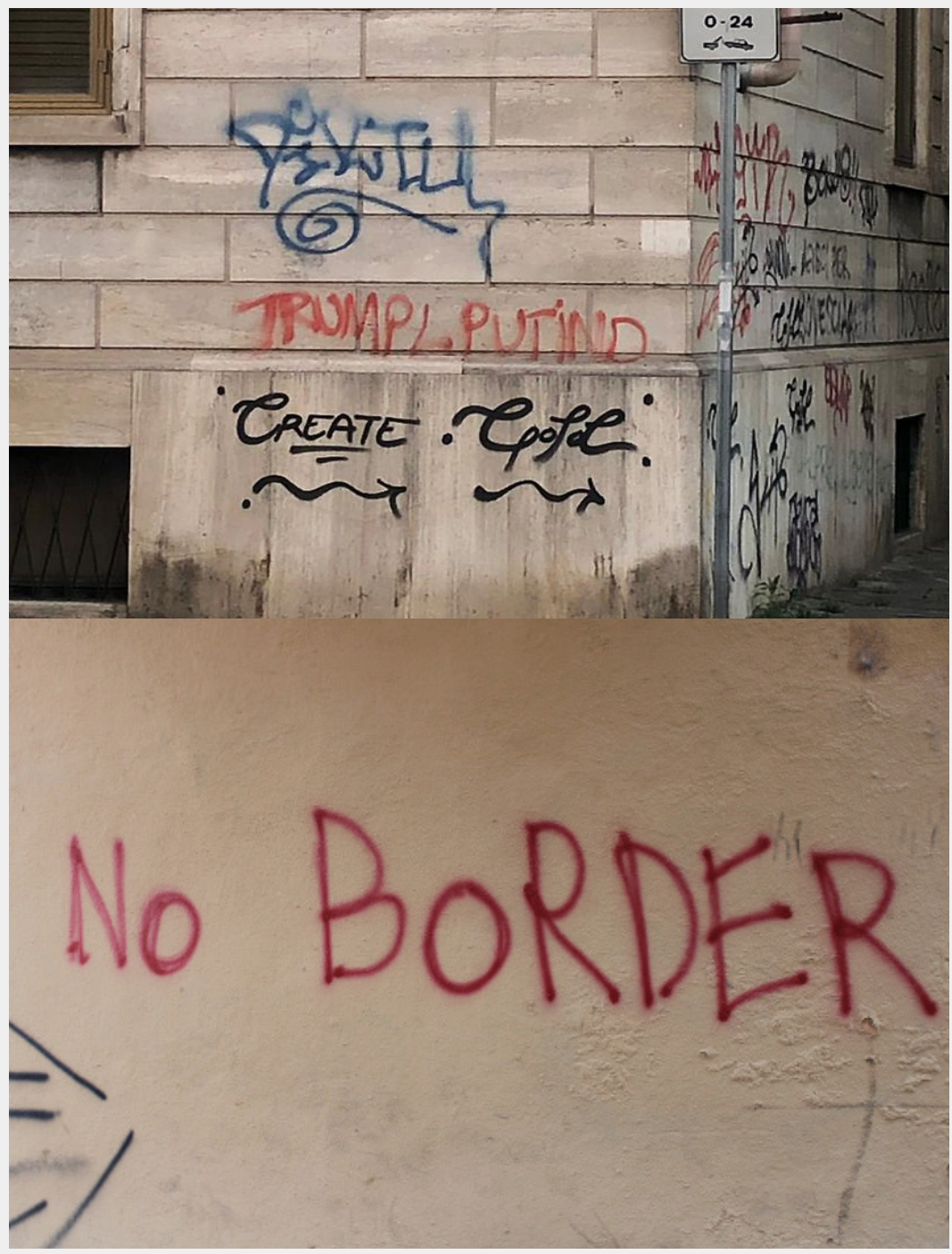

officials, and would have more liberty in choosing where they settle down. ${ }^{65}$ The banning of borders also interests Italy as the state would have less responsibility when it comes to granting immigrants asylum. Italy argues that it does not have enough resources to provide for hundreds of thousands of immigrants. ${ }^{66}$ However, there have been reports that reveal that Italy has been paying Libya' government to keep refugees out of Italy. ${ }^{67}$ This money could be put towards aiding immigrants in their arrival to Italy instead.

Unfortunately, immigration presents controversy and complications in other countries as well. The United States has seen a similar influx of immigration in recent years, and has been met with worsening conditions as a result of Donald Trump's presidency. ${ }^{68}$ Legal immigration was made much more difficult than in the past, deportations became more common, and many families were detained and separated at the border. ${ }^{69}$ These poor immigration conditions defined Trump's presidency around the world, resulting in graffiti that drew comparisons between Trump himself and the devil. In addition, graffiti calling him a "putino" or a "son of a bitch" is also seen around Italy.

Fittingly enough, the dialogue surrounding the controversy at the borders is taking place on walls-structures that, like borders, are meant to separate people. ${ }^{70}$ However, with solidarity and compassion, Italy has a better chance of protecting immigrants, asylum seekers, and refugees.

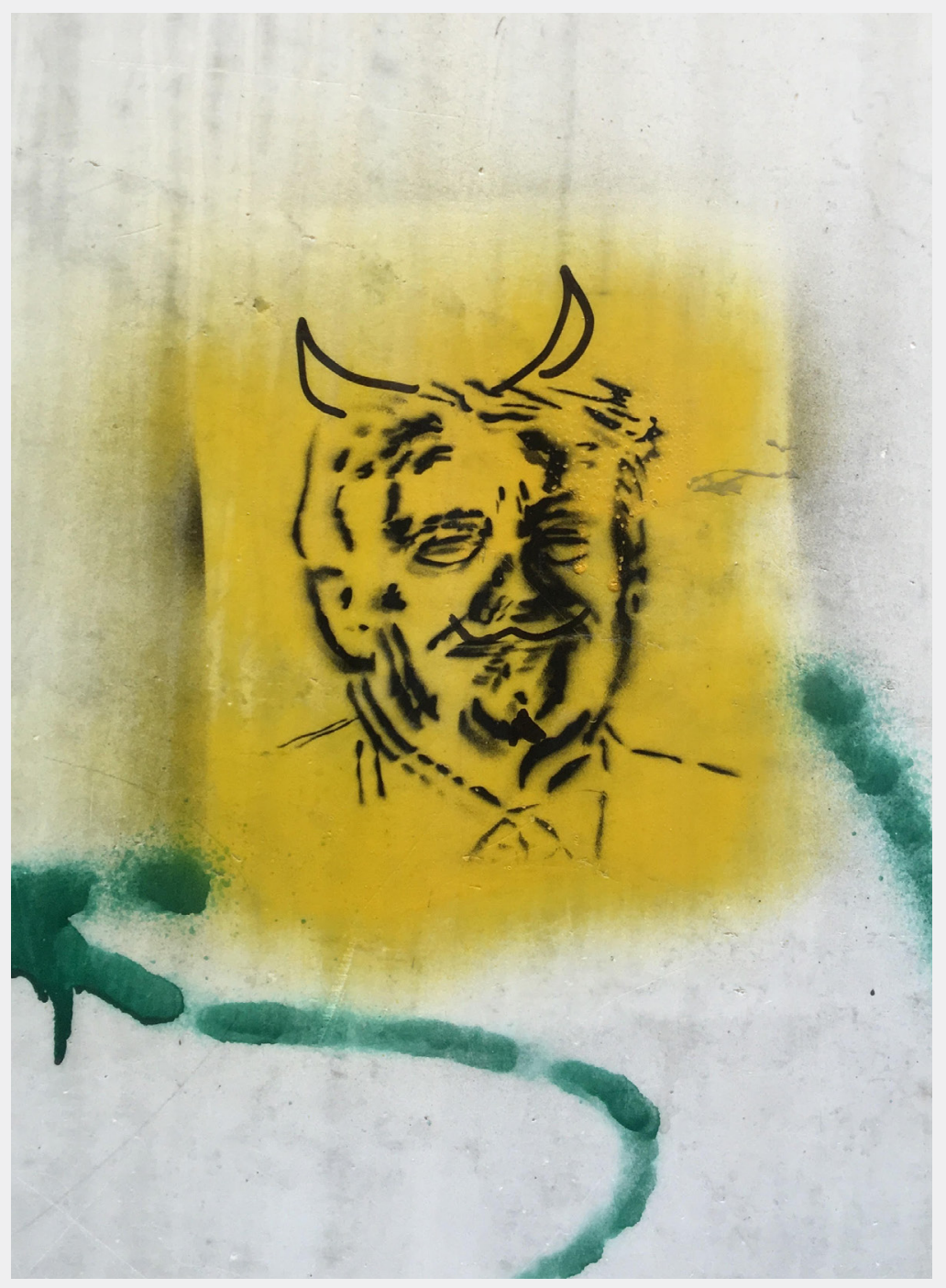




\section{GRAFFITI AS A BYPRODUCT: THE}

Throughout the Berlusconi and Salvini administration, other groups besides immigrants have faced aggression.Violence against women has grown, as well as its normalization. The lack of effective legislation and political action not only fails the 150 Ital- $^{-}$ ian women that are killed by their abusive partners each year, but the 22,000 of them currently living in a limited amount of shelters. ${ }^{71}$

Women do not receive the support they need from legislators. Women who face abuse often wait two years to see their cases discussed in court, and three to ten years to receive a definitive ruling. ${ }^{72}$ The role of Minister for Equal Opportunities was established for women to have legislative support and protection, but this position was abolished by the right-wing government. ${ }^{73}$ As a result, there is no central coordination for gender-violence legislation or institutions to protect Italian women. ${ }^{74}$

A plethora of Italian graffiti speaks to the need to fight for women. The graffiti surrounding women's rights tends to be heightened through linguistic and stylistic choices of the author and is often accompanied by graphics.

Amongst these sophisticated writings is graffiti that reads "LOTTO MARZO / TUTTO L'ANNO." This graffiti is complex in that it is a play on words and can be broken up into two distinct phrases. "LOTTO" functions as both a verb and a contraction in this graffiti. While the word "lotto" means "to fight", the distinction of color suggests it can also be read as "l'otto", which means "the 8th." Through the division of the words and the implementation of color to differentiate the two meanings of "LOTTO," the reader gets two separate sentences from this graffiti.

The first one skips over the word "MARZO" to read "I fight all year round", while the next one reads "The 8th of March all year round." This graffiti subtly refers to protecting women and their rights as March 8th is international women's day. Yet, the graffiti reiterates that we should be fighting for women year-round given that every day is international women's day. This play on words is seen throughout other graffiti, including that of a woman ready to fight and strike back.

Another complex feminist writing includes one that blurs the lines between graffiti and street art. The artist depicts Florence's most well-known monuments through black demon-like figures with wide eyes and sharp teeth. The writing itself is not in the author's original handwriting, it is in a bubbly font. The writing reads "THE SOLE SECURITY AND LIBERTY \& RIGHTS FOR ALL!" indicating that womens' rights are human rights. However, what is especially significant about this writing is that "all" is represented by "tutti/e."

The Italian language assigns a gender to all of its nouns. When referring to a group of mixedgender individuals, the masculine form of the noun is used. Yet in this case, the author asserts that females must be represented in this statement as their own entity. By only including the masculine version of the word, the author would be displacing women from both their current and past struggles.

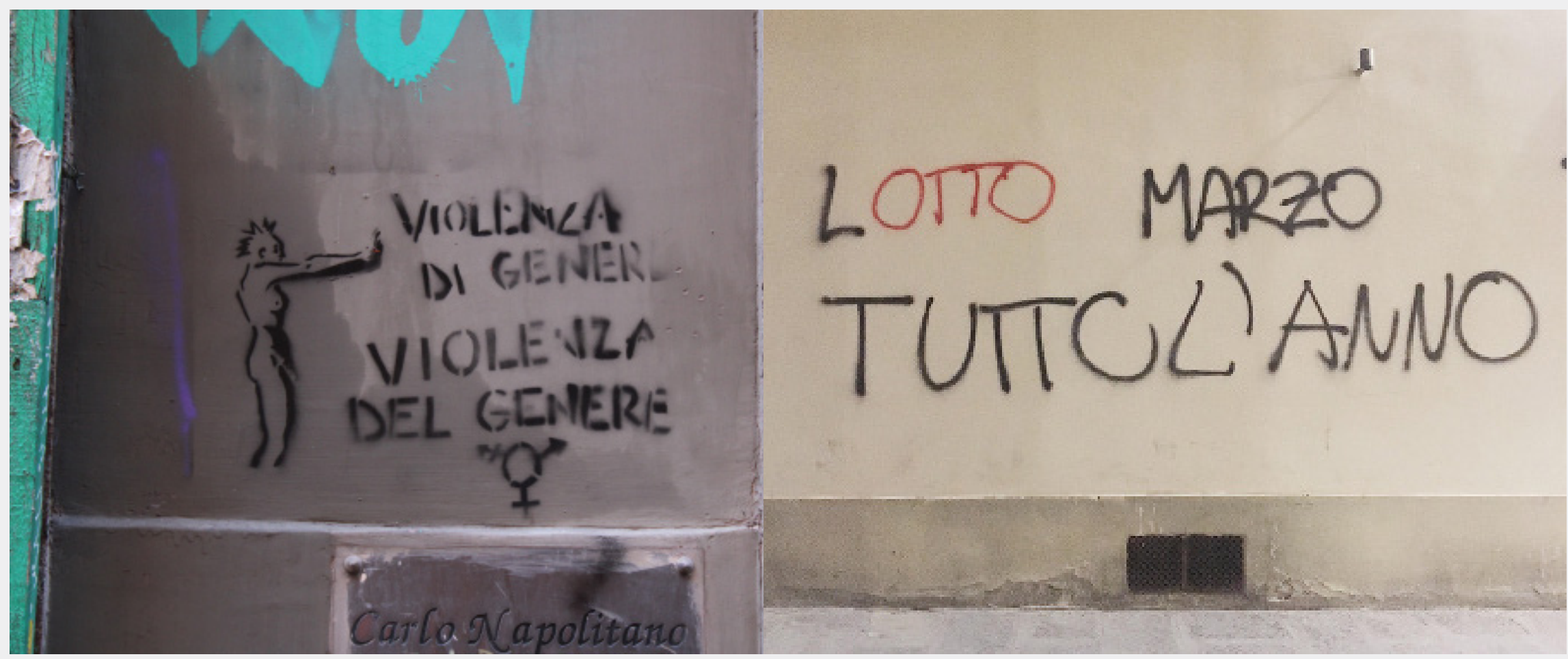




\section{EXPANSION OF ITALIAN FEMINISM}

While it is easy to assume that women are the authors of graffiti similar to those that read "FEMINISM OR BARBARITY", there has been a surge of male activism through pro-feminist as sociations.

The main pro-feminist association is called Maschile Plurale and started in the mid 1980s as an informal group practice where men would take part in in-depth discussions. ${ }^{76}$ In 2007, it became a national association, expanding to a plethora of large Italian cities including Rome, Florence, Milan, Bologna, Turin and more. ${ }^{77}$ Today, men discuss problems that originate from discourses and practices of normative masculinity in order to dissolve toxic male behavior against females. ${ }^{78}$ In response, graffiti of a gender neutral person is found pushing against the words "STOP GENDER VIOLENCE", replicating the need to bring it to a halt.

Given that graffiti is a male-skewed practice both nationally and internationally, it is possible that male activism is transcending these focus groups and networks and entering the public sphere through graffiti. ${ }^{79}$ By changing the discourse surrounding masculinity, a real conversation about gender violence has emerged through graffiti.

\section{THE REVOLUTION WUILL BE FEMIIIST, OR IT WOח'T BE AT RLL}

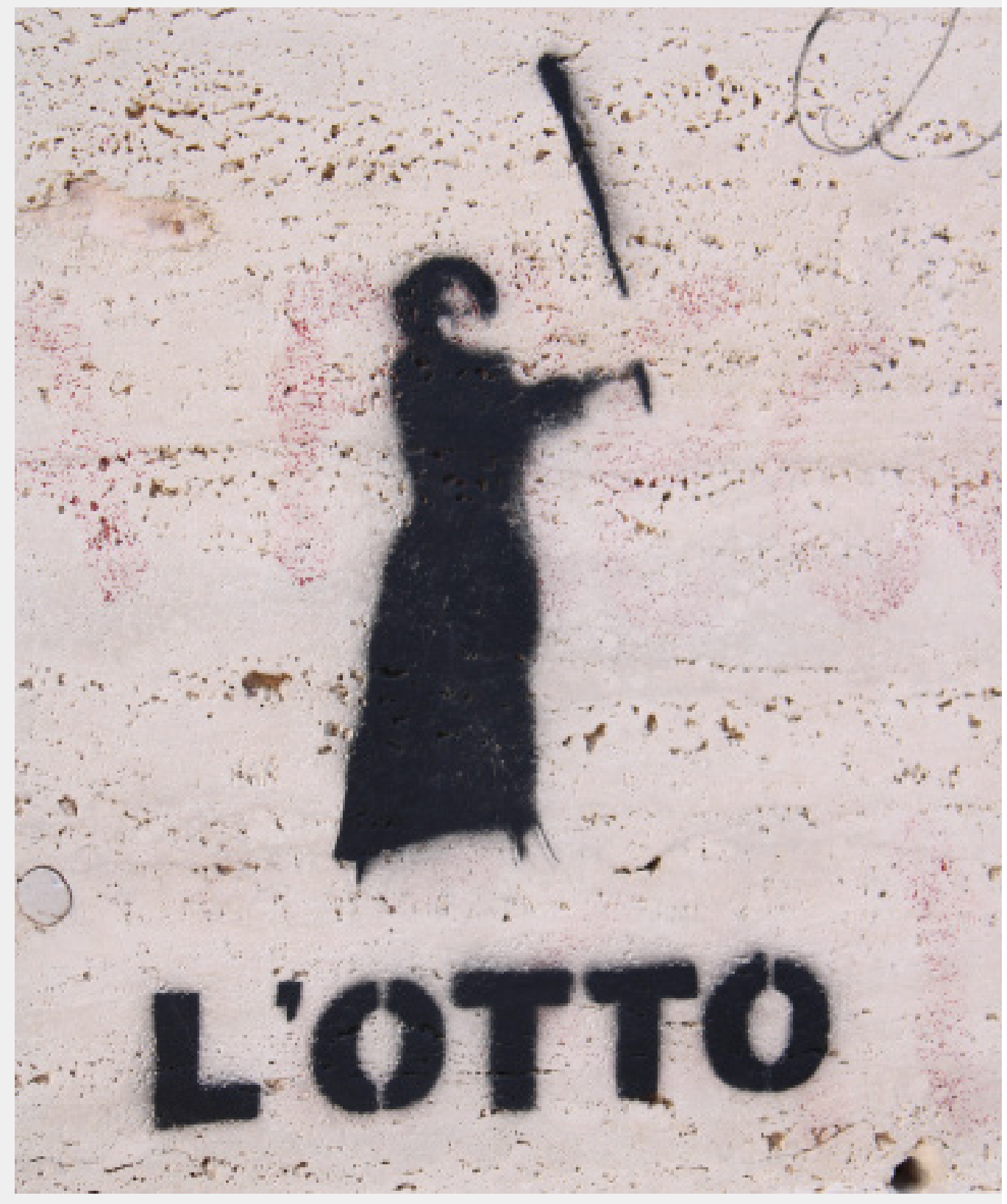

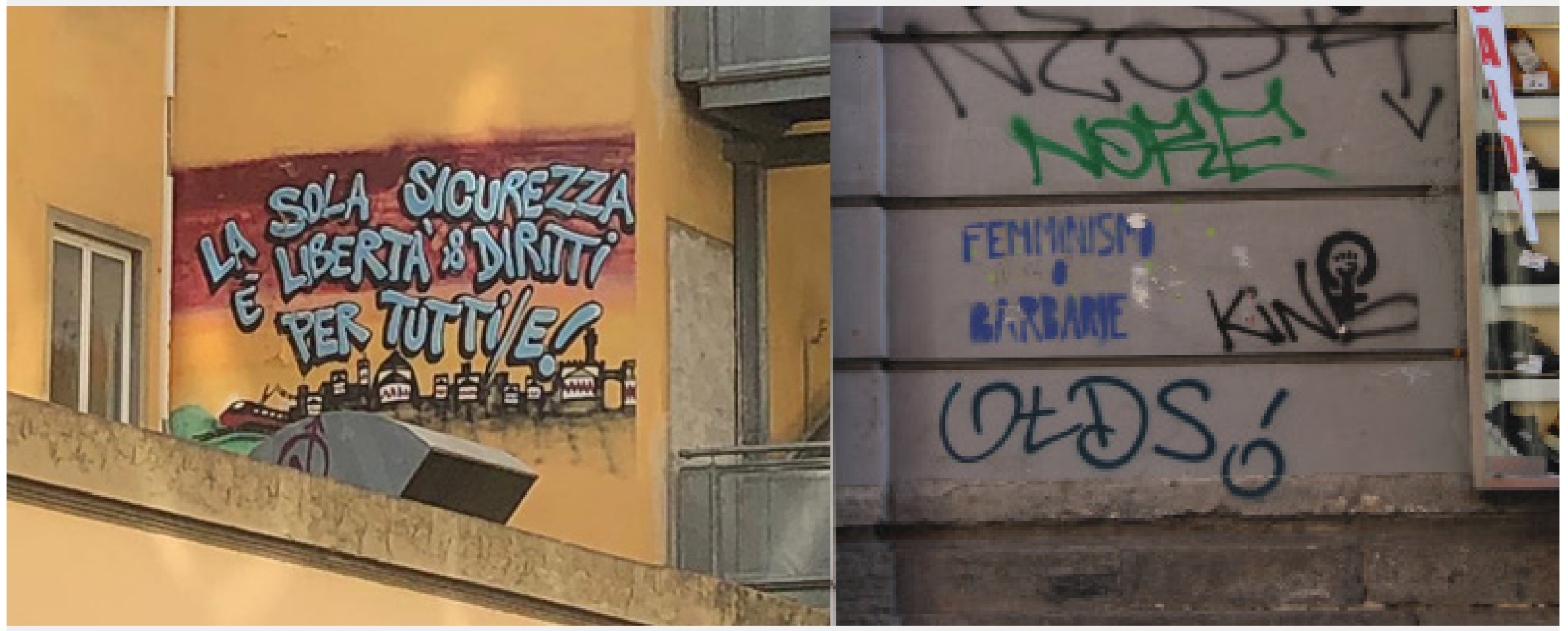




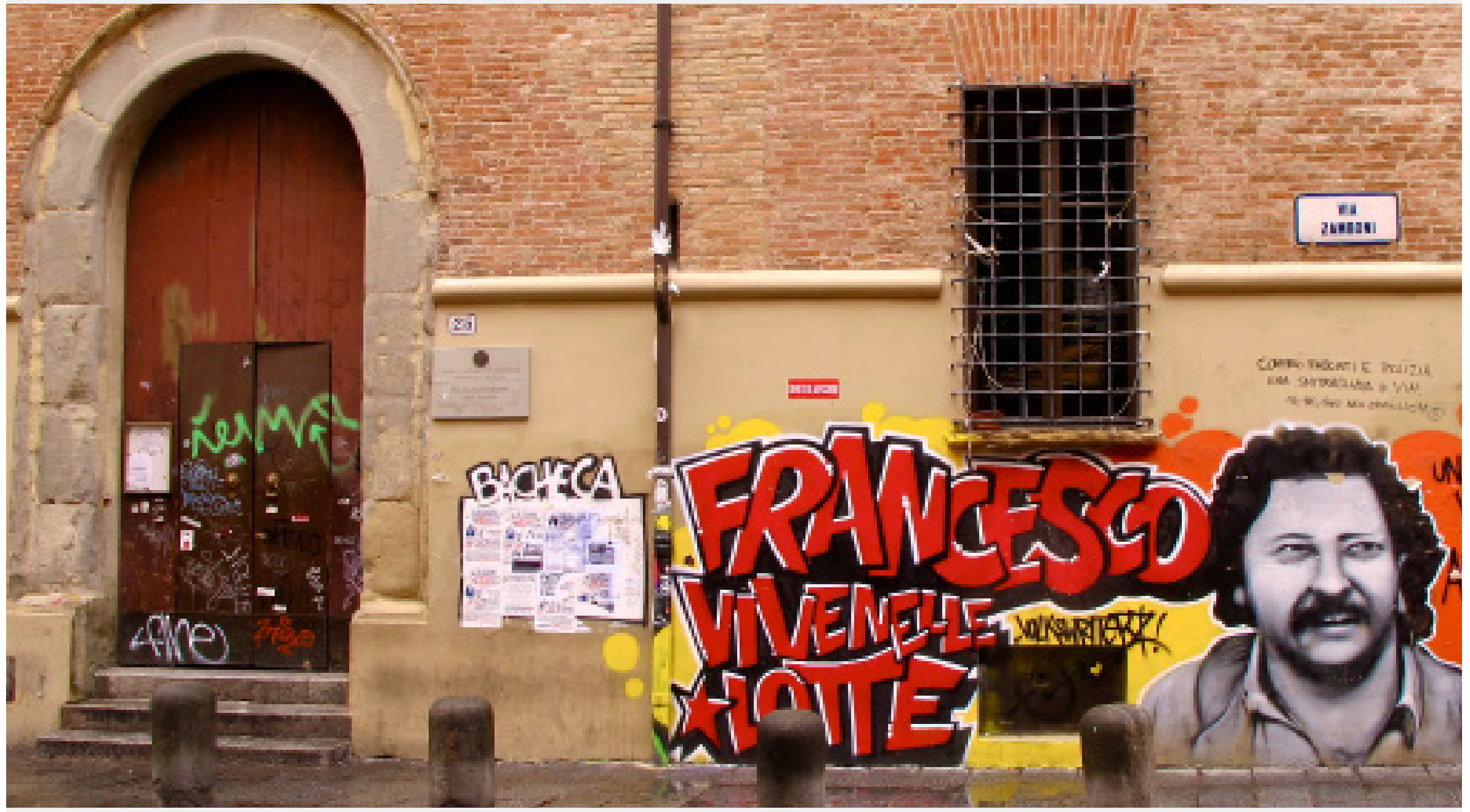

\section{Students as Graffiti Crews}

Although there is a general understanding of who is responsible for the graffiti pertaining to certain social groups, is there a population that is more inclined to partake in its production?

In Italy, the culture surrounding organized student groups is closely linked to acts of economic and political resistance. While students have always taken part in traditional forms of protest, they began creatively appropriating urban space in order to fuel movements.

By the late 1960s, students were enhancing protests by weaving theatrical performances, live music and costumes into marches and demonstrations ${ }^{80}$ Ses- $^{-}$ santotto (1968) was a predominantly student-led movement that protested the capitalistic culture and society that had expanded in Italy. ${ }^{81}$ Many of the strikes and occupations that started in Bologna, a city widely known for its universities, spread to different parts of the country along with the creative components that it incorporated. ${ }^{82}$ Student activists in Bologna expressed themselves through the creation of autonomous magazines and other means of counter-propaganda, including graffiti. ${ }^{83}$

Student activists creatively claimed public spaces by using irony and slogans in graffiti, and memorializing the loss of Francesco Lorusso, a fellow student violently killed in police clashes. ${ }^{84}$ To this day, the streets in Bologna and neighboring cities still reference the events of Sessantotto and continue to $\mathrm{ex}^{-}$ press that "Francesco lives in the fights."
Although graffiti as a form of student protest began within universities, contemporary research suggests that initial interest in the practice began at an earlier age. In 2009, the University of Bologna interviewed 162 Italian adolescents who had a fascination with graffiti. Although the mean age of this sample was 17 , students revealed that their first interaction with graffiti began when they were in middle school.85 Many noticed writings around town, so they began writing their own names on the bathroom stalls, also known as "tagging." 86 As they became more familiar with the practice, they began tagging in more open, public spaces such as town walls and buses. ${ }^{87}$

Given that no prior research addresses this question, it is important to ask when student-produced graffiti becomes politicized. Throughout the major Italian cities of Florence, Bologna, and Naples, school walls are covered with sociopolitical graffiti. They reference the re-emergence of fascist practices, and that their respective cities will fight back. Interestingly enough, these productions are found on the walls of schools of varying education levels.

At a middle school in Florence, slogans such as "Get Fascists out of SCHOOLS" along with "FLORENCE FIGHTS BACK" can be found. Interestingly enough, they seem to have a history of transformation and suppression. Thecurrent productions have a couple of words printed over what looks to be white paint. It makes the 


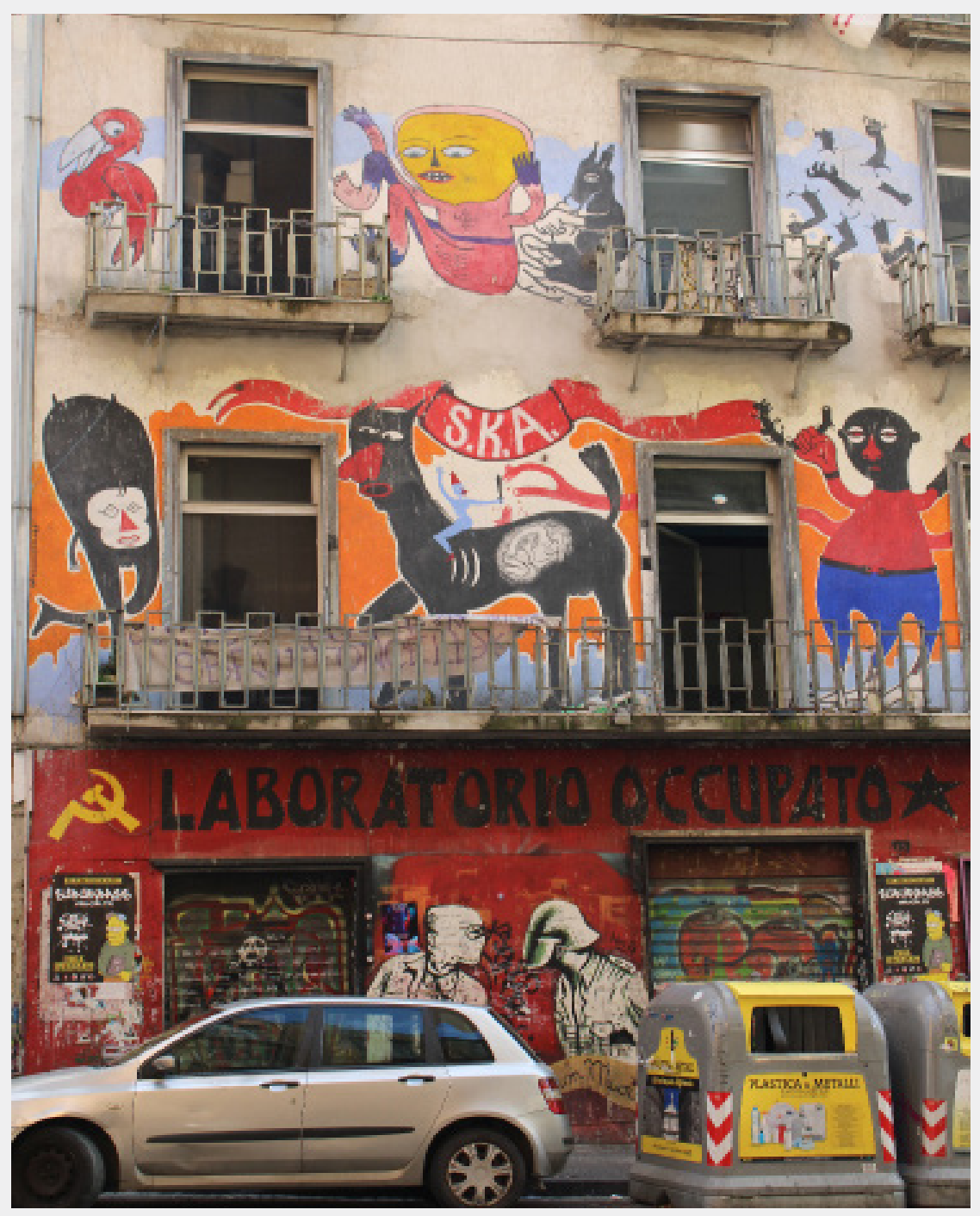

observer question what was underneath the white paint before it was painted over, and what the author is trying to transform or suppress.

These practices begin to represent the responsibility students and young graffiti writers take on in fighting fascism and right-wing ideas.

While high schools and universities also have slogan graffiti written on their walls, these productions become more elaborate. Murals with narratives are commonly seen plastered on the walls of many higher education buildings, as well as areas surrounding universities. These productions likewise reinforce anti-fascism and promote other forms of governments.

Graffiti becomes "a weapon against institutions, the establishment, powers that be, it allows me to go against it all." 88 Not only is graffiti a form of resistance, but it is also a manner in which young individuals express their right to political representation. Italy does not grant citizens full democratic power until mid-their 20s, hindering young adults from voting for the country's prime minister. ${ }^{89}$ In addition, many individuals who were born in Italy but do not come from Italian blood also do not receive voting privileges. ${ }^{90}$ For this reason, graffiti expresses the need to "fight instead of voting."

Groups of students have come together for the purpose of fighting injustice. As a result, they have also formed a community of graffiti writers who inadvertently, have become a graffiti crew.
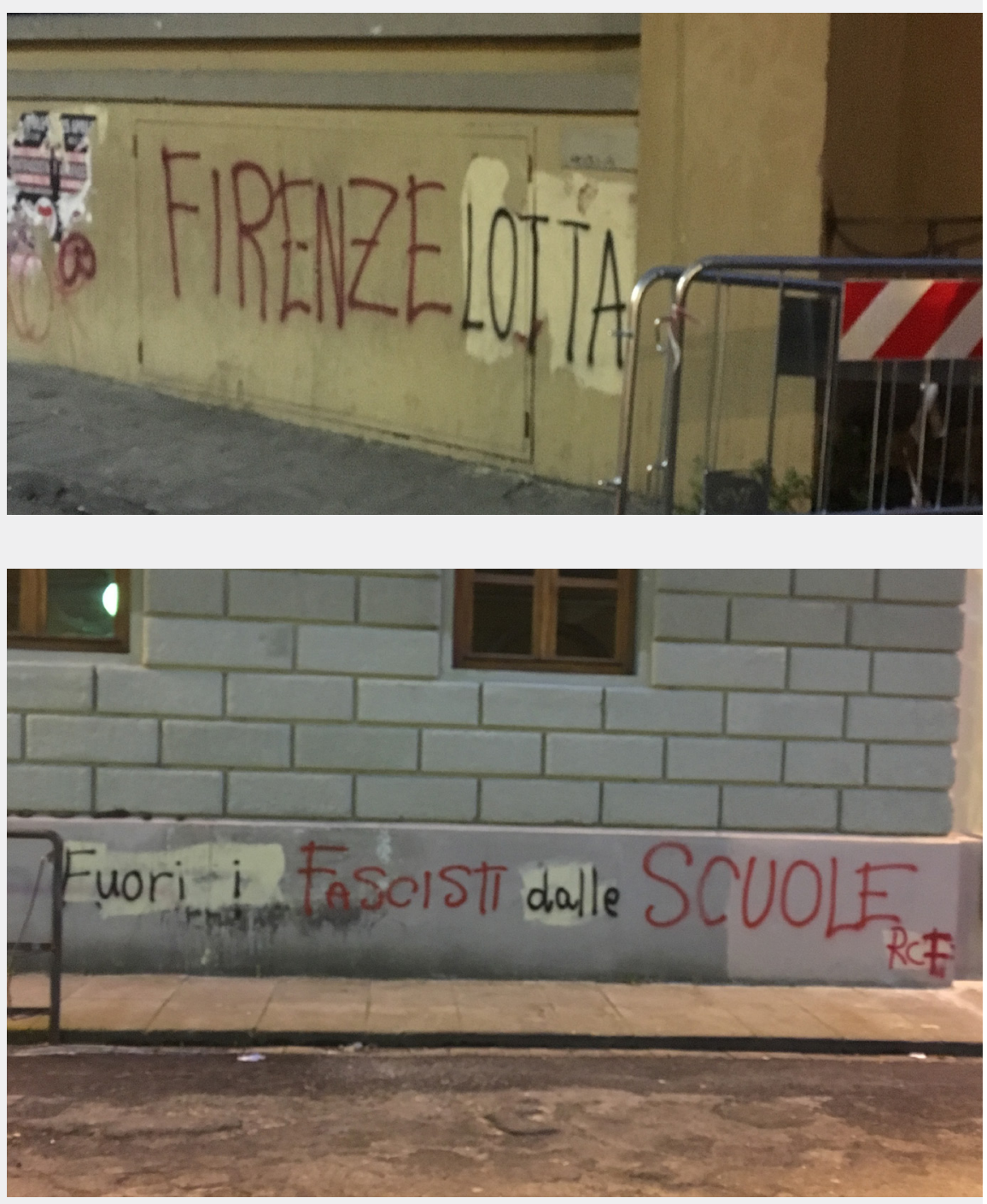

\section{"NON VOTARE, LOTTARE!"}

\section{"DON'T VOTE, F I G H T ! A'}

\section{"NON VOTARE. LOTTARE!"}




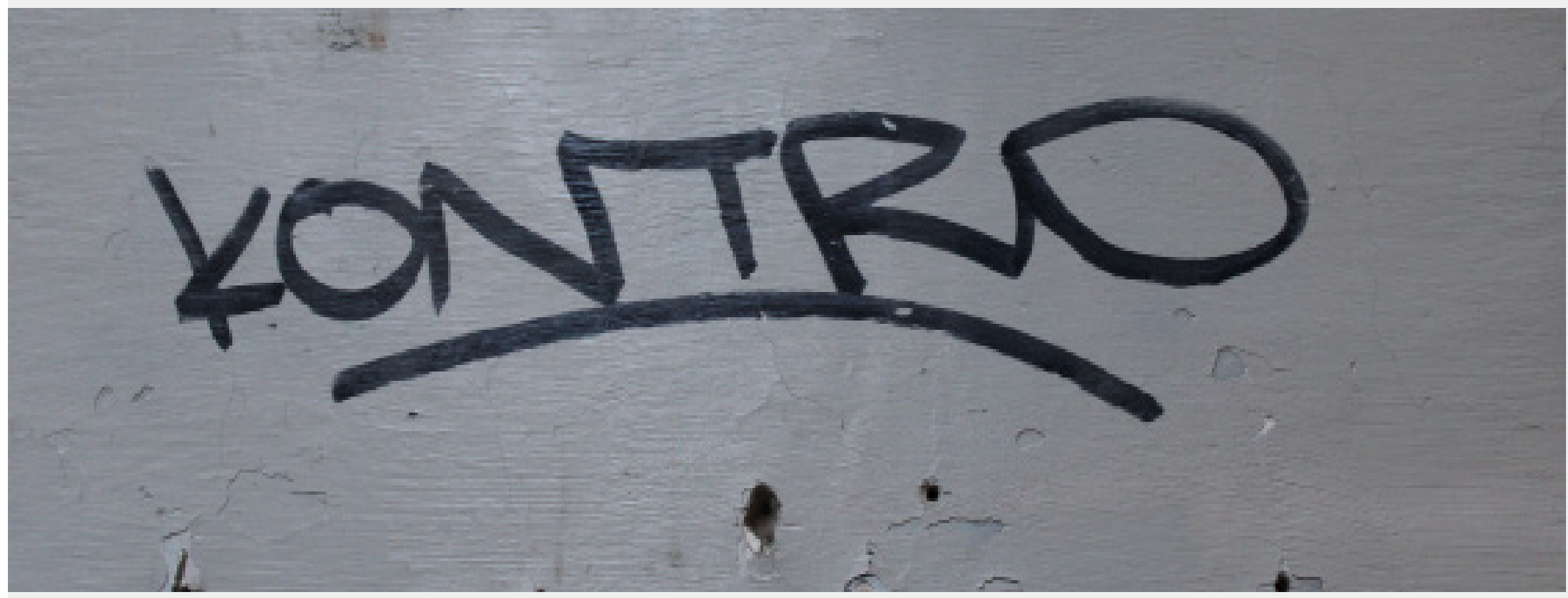

\section{SARDINIA,}

Sardinia is one of Italy's 20 regions and is characterized by extreme sociopolitical tension. ${ }^{91}$ While graffiti in Italy notoriously responds to overarching national issues, Sardinia's graffiti takes a local approach to addressing issues and interests specific to the region.

Sardinia is known for its immense nationalism, which has led the region to attain a degree of autonomy. ${ }^{92}$ The region historically sides with leftist politics and fights for further self-determination and an end to Italiannationalism and fas ${ }^{-}$ cism. ${ }^{93}$

One of the most recent movements that has received activism through graffiti is Sardines Contro Salvini or Sardines Against Salvini. ${ }^{94}$ The word "CONTRO" often represents the movement and is interestingly printed on the walls of both mainland and island cities.

"Contro" is also seen written in Sardinian with a "K.," 95 further establishing Sardinia's immense nationalism. Even when far from home, Sardinians partake in Sardinia-specific anti-fascism fighting racial discrimination, right-wing populism and verbal violence.

The linguistics of Sardinian graffiti is arguably more complex than graffiti found in mainland Italian cities. Giovanni Depau is an Italian linguist who has studied the sociolinguistic environment of graffiti in the Sardinian capital of Caligari. In How Graffiti Provide Evidence on the
Relationship between Writing, Orality and Identity, Depau explains that the graphic choices made by Sardinian graffiti artists often provide indications of its function and purpose.

Like in graffiti found in the north and south of Italy, politically oriented writings tend to be explicit in content and explicit towards their addressee. ${ }^{96}$ However, Sardinian graffiti becomes distinct from other graffiti in Italy given the use of non-standard orthography. ${ }^{97}$

\section{ONE OF $A<K>I N D$}

In graffiti written in both Italian and Sardinian, the grapheme $<\mathrm{k}>$ is used to represent $/ \mathrm{k} /$ which substitutes $<\mathrm{ch}>$ and $<\mathrm{c}>$. ${ }^{98}$ The replacement of $<\mathrm{ch}>$ or $<\mathrm{c}>$ by $<\mathrm{k}>$ is typically employed when conveying leftist ideas. ${ }^{99}$

One example of this practice involves graffiti addressing the ex-prime minister of Sardinia. Francesco Cossiga was the prime minister during the 1960 s and 1970 s, and is perceived responsible for the countless lives lost during the riots and political instability. ${ }^{100}$ Alluding that he is a murderer, the author replaces the $<\mathrm{C}>$ in his name to a $<\mathrm{K}>$. Transforming his name into "Kossiga", instead of "Cossiga", heightens the visual effect of the graffiti. ${ }^{101}$ The use of the $<\mathrm{k}>$ and the double $<_{\mathrm{s}}>$ references and takes the form of swastikas, which emphasizes Cossiga's connection to aggression and fas ${ }^{-}$ cism. ${ }^{102}$

A growing amount of graffiti in Sardinia is being written in the regional language and alludes to Sardinian separatism. A graffiti writes "No a su nikleari" and "Kontr'a su kolonialismu" which respectively mean "no to nuclear" and "against colonialism." 103

In addition, Sardinian graffiti also employs the use of other graphemes in place of particular letters and sounds in order to establish that the dialect is different from the dominant Italian language. ${ }^{104}$ Examples include $<$ nny $>$ for $<$ n $>$, $<$ lly $>$ for $<$ y $>$, and most commonly $<$ tz $>$ instead of $<\mathrm{ts}>$. ${ }^{105}$ These graphemes were solely found in politi- cal graffiti, again, referring to Sardinia's selfdetermination. ${ }^{106}$

Although the graffiti in Sardinia functions similarly to the other graffiti found in Italy, its graphic style and linguistics are more complex. As a result of Sardinian graffiti's heightened form, authors can subconsciously provoke their audiences beyond what is just written. 


\section{THE LGBTQ COMMUNITY STRIKES BACK, AND THIS TIME, THROUGH GRAFFITI}

I taly is structurally defined by three institutions: governent, church, and family. ${ }^{106}$ Since the country's formation, these institutions have heavily overlapped, creating state and family organizations that are heavily influenced by the church. ${ }^{107}$ Nevertheless, Italy is defined by a very traditional culture where anything straying from institutional beliefs is considered erroneous. As a country built upon tradition, disapproval of the LGBTQ community is not uncommon.

While many consider Italy to be a "gay-friendly" country, given their anti-discrimination laws and the legalization of same-sex marriages and gender reassignment, ${ }^{108}$ homophobia still prevails.

Within the last five to ten years, severe hate crimes have been reported. ${ }^{109}$ Gay centers around the country have fallen victim to these attacks, as well as individuals who have been critically injured. ${ }^{110}$ While these attacks are rare, homophobia commonly disseminates through rhetoric.

Hate speech is both present in national media, and in smaller communities. ${ }^{111}$ In response, the LGTBQ community has used graffiti as a way to reclaim the aggressive rhetoric used against them in order to repress its power and effect.

The most common anti-LGBTQ slur used is "frocio," which translates to "faggot." This word is seen conjugated in all of its forms and written on a plethora of Italian walls. Surprisingly, there is reason to believe that it is graffiti created by the LGBTQ community itself.
Along the Arno, the river that runs through the middle of Florence, one can come across an abandoned house. This house is stained with forceful language, using LGBTQ slurs in provocative ways. The LGBTQ com munity has used graffiti as a way to regain agency and power over those who use slurs against them. But how do we know for sure this house belongs to the community and is not an aggressive attack on the community?

In marking their territory, the LGBTQ community has graffitied"CASA FROCIA" above the doorway, as wellas "TRANSQUEER ZONE" on a cement block in front of the house. Other indications that suggest that th graffiti was created by LGBTQ individuals themselves are references to the events that took place at Stone wall and transgender imagery followed by "RIVOLUZIONE FROCIA.

Additional powerful language present at the site includes "HE CALLED ME A FAGGOT SO I CALLED HIM AN AMBULANCE”, “AQAB” (ALL QUEERS ARE BASTARDS), and "FORGIVE ME PIL," referencing the HPV virus. These writings are also found on white sheets that seek revenge against homophobic assassins, and the liberation of those affected by LGTBQ aggression. Many of the graffiti writings reference ending patriarchy and anarchy.

Although this house is abandoned, the LGTBQ community' presence is heavily felt through their fight against hat speech and rhetoric. Through graffiti, the community ha been able to suppress the language that has repeatedly hurt them. 

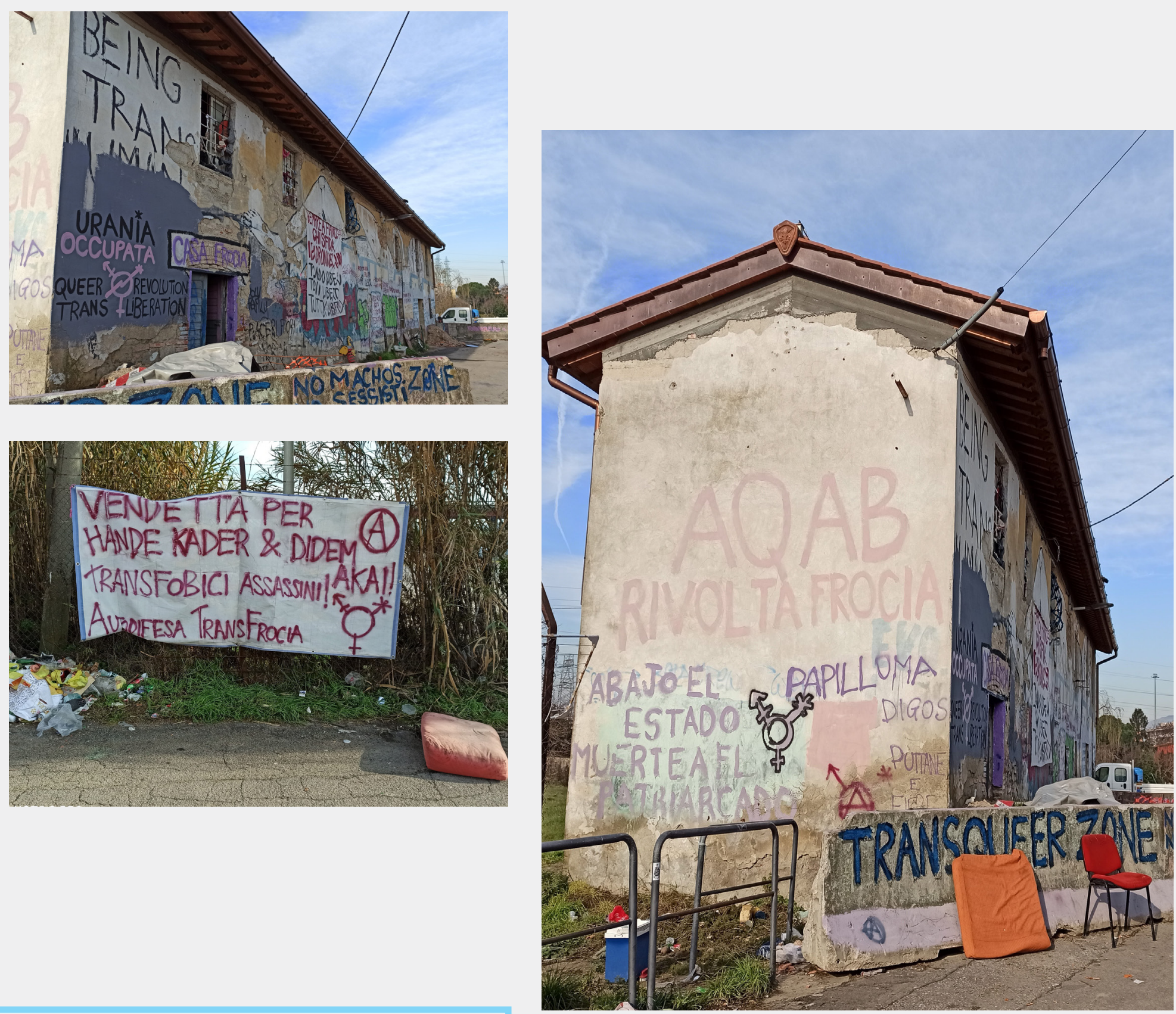

\section{${ }^{66}$ THIS IS OUR HOUSE,}

VENUE TTA PER HANDE KADER \& DIDEM (A) TRANSFOBICI ASSASSMIIAKAI! AUaDIEESA TRANSFROCA
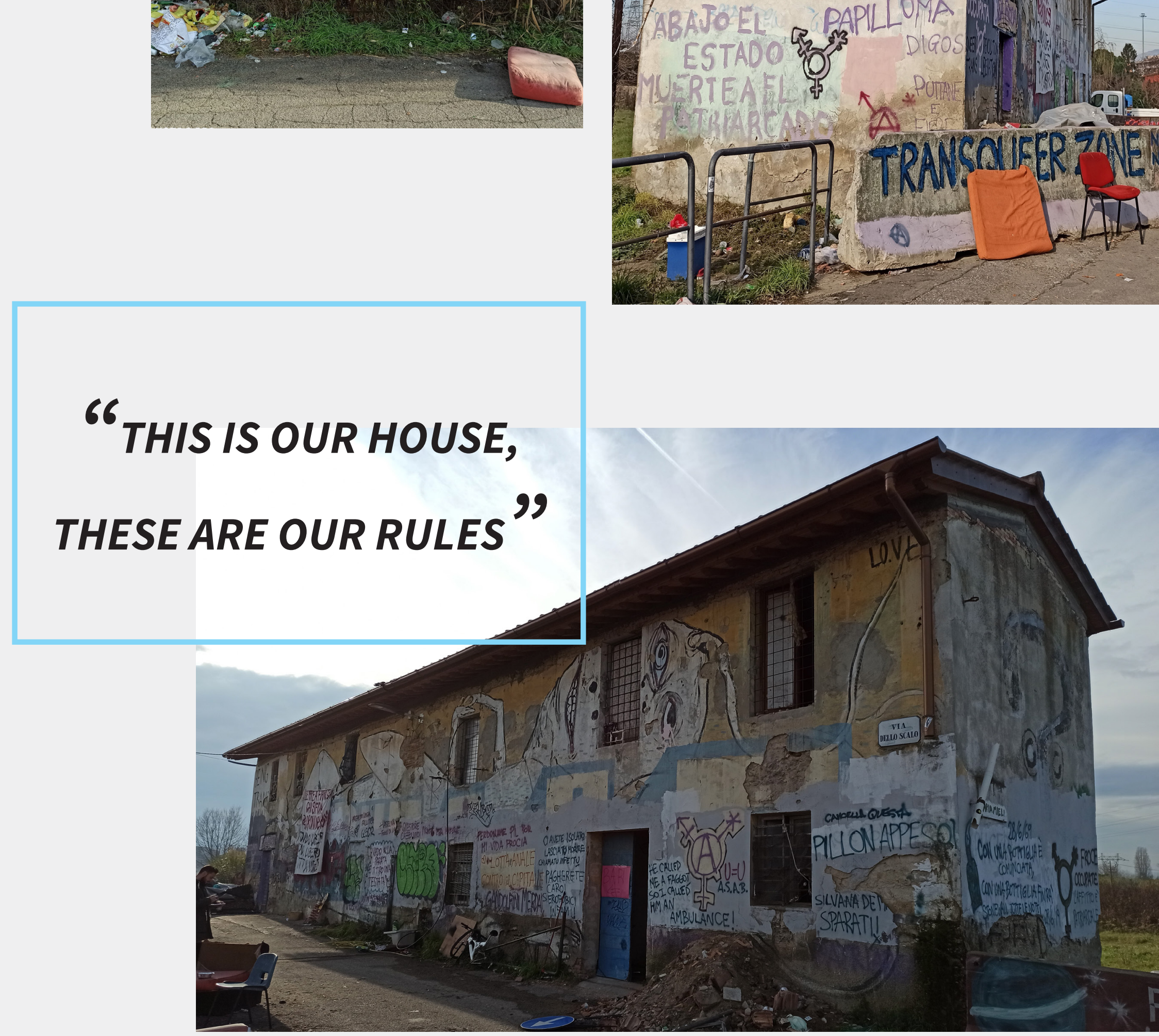


\section{THE STAINED REVOLUTION LIVESON}

Italian graffiti doubles as a way of informing outsiders about the complex sociopolitical climate of the country, while also responding to the government about controversial sociopolitical topics. Although graffiti speaks to a myriad of issues the nation currently faces, it has the singular purpose of rebelling against the ideology advertised by the right. From understanding which causes graffiti is addressing, to understanding who is producing this graffiti, La Rivoluzione Macchiata establishes an understanding of the practice and its function in both history and present-day society.

I roamed the streets of Italy looking for an understanding of the culture and people I was surrounded by. Instead, I found myself sucked into a revolution I did not even know existed. I had become part of the stained revolution, and now you have too.

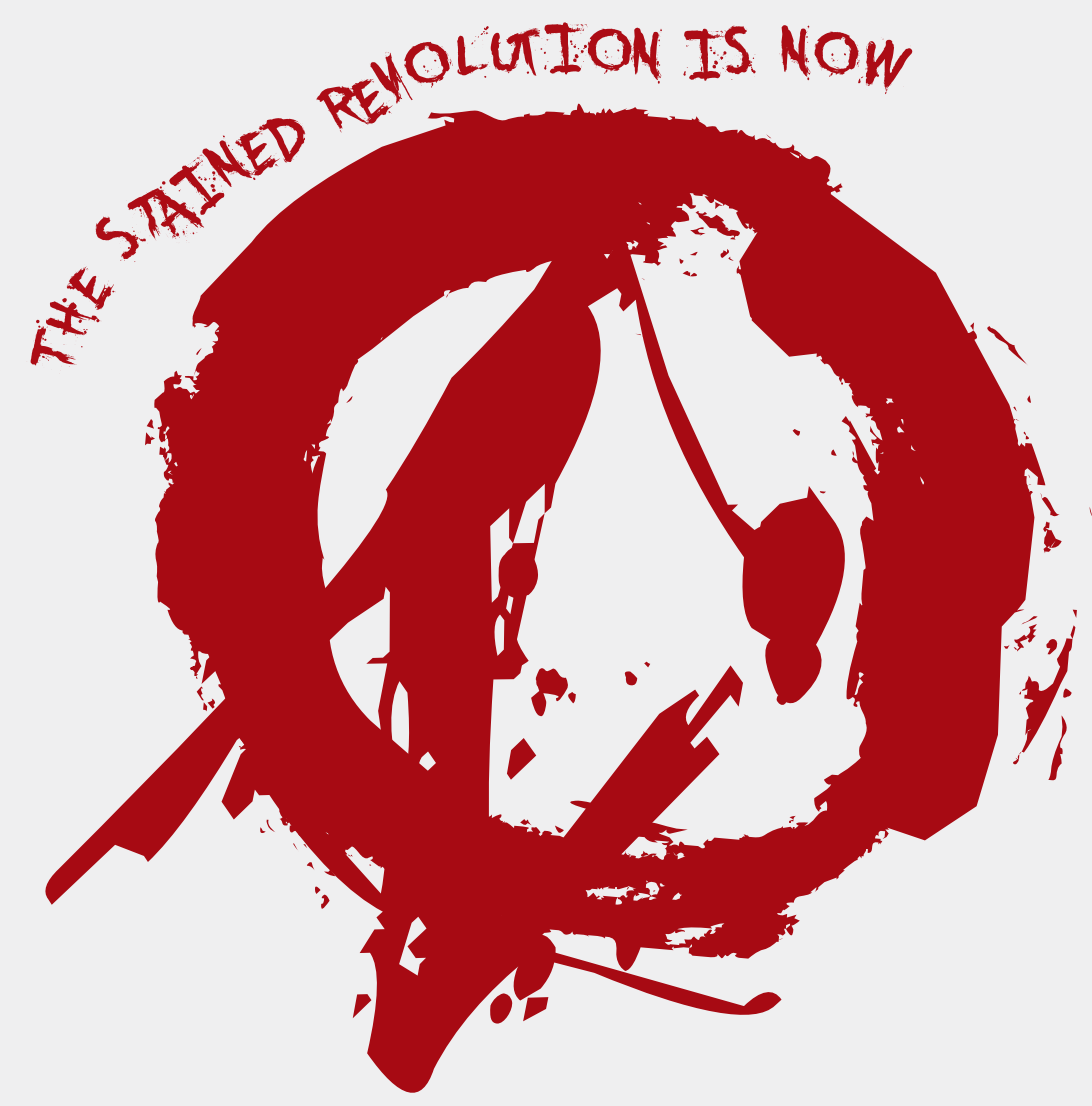




\section{ACKNOWLEDGEMENTS}

This is a revised version of my senior thesis, which would not have initially been possible without the support of my friends, family, and the NYU community. I want to thank the GLS committee for awarding me the Dean's Global Research Grant in full, which allowed me to continue my research in Italy for the duration of January 2020. In addition, I want to thank professor Matthew Longabucco for his continual guidance throughout the creative process, as well as the staff at NYU Florence for providing me academic support even after having completed my abroad program. Thank you again for your unwavering commitment to this project, it wouldn't have been possible without you all. Cheers!

\section{END NOTES}

1. Marcello Balzani, et al., "Digital Representation and Multimodal Presentation of Archeological Graffiti a Pompei," VAST 4 (2004): 93-103, https://doi.org/10.2312/VAST/VAST04/093-103.

2. Ibid.; Marco La Rocca, "LGBTQ: Landscapes of Gentrification Building up in Turin: The Quadrilatero," (per presented at the III European Geographies of Sexualities Conference on Crossing Boundaries: Sexu alities, Media and (Urban) Spaces, Rome, September, 16-18, 2015).

3. Cameron McAuliffe, "Graffiti or Street Art? Negotiating the Moral Geographies of the Creative City," Jour nal of Urban Affairs 34, no. 2 (2012): 189-206, https://doi.org/10.1111/j.1467 9906.2012. 00610.

4. Balzani, "Digital Representation," 93-103.

5. Ibid.

6. Troy R. Lovata and Elizabeth Olton, eds., Understanding Graffiti: Multidisciplinary Studies from Preh story to the Present (London: Routledge, 2016).

7. Jonathan Mullins, "The Everyday Timings of Dissent: The Ephemeral Media of the Radical Left in the 1970s Italy" (PhD diss., New York University, 2015), 1-279.

8. Adrian Lyttelton, The Seizure of Power: Fascism in Italy 1919-1929 (London: Routledge, 2004).

9. Mullins, "The Everyday Timings of Dissent," 1-279.

10. McAuliffe, "Graffiti or Street Art?" 189-206; A. James Gregor, Italian Fascism and Developmental Dictato ship (Princeton: Princeton University Press, 2014).

11. Andrea Mubi Brighenti, "At the Wall: Graffiti Writers, Urban Territoriality, and the Public Domain," Space and Culture 13, no. 3 (2010): 315-332, http://doi.org/10.1177 /120633 1210365283.

12. Balzani, "Digital Representation," 93-103; McAuliffe, “Graffiti or Street Art?" 189-206; Lovata, Understand ing Graffiti.

13. Brighenti, "At the Wall," 315-332.

14. Lyttelton, Seizure of Power; Hamish Macdonald, Mussolini and Italian Fascism (Nashville: Nelson Tho as, 1998).

15. Ibid.

16. Ibid.; Simon Martin, Sport Italia: The Italian Love Affair with Sport (London: I.B. Tauris, 2011).

17. Macdonald, Mussolini and Italian Fascism.

18. Ibid.

19. Gregor, Italian Fascism.

20. Mullins, "The Everyday Timings of Dissent," 1-279.

21. Ibid.

22. Catherine Edwards, "Tension in Florence after Immigrant Is Shot Dead," The Local IT, March 7, 2018, http://www.thelocal.it/20180307/tension-at-protests-over-murder-of-immigrant-in-central-florence/.

23. Gregor, Italian Fascism; Lyttelton, Seizure of Power; Macdonald, Mussolini and Italian Fascism.

24. Lovata, Understanding Graffiti; Martin, Sport Italia.

25. Lyttelton, Seizure of Power; Macdonald, Mussolini and Italian Fascism.

26. Macdonald, Mussolini and Italian Fascism.

27. Ibid.

28. Tobias Jones, "The Fascist Movement That Has Brought Mussolini Back to the Mainstream," The Guar ian, February 22, 2018, http://www.theguardian.com/news/2018/feb/22/casapound-italy-mussolini-fascism mainstream; Macdonald, Mussolini and Italian Fascism.

29. Eva Garau, "The Northern League and the Debate on Identity and Immigration," in Politics of National Identity in Italy: Immigration and 'Italianità' (New York: Routledge, 2014), 102-144; Jones, "Fascist Mov ment"; John Richardson, and Monica Colombo, "Continuity and Change in Anti-Immigrant Discourse in I aly: An Analysis of the Visual Propaganda of the Lega Nord," Journal of Language and Politics 12, no. 2 (2013): 180-202, https://doi.org/10.1075/jlp.12.2.02ric. 
30. Ibid.

31. Garau, "Northern League," 102-144.

32. Rinella Cere, "Globalization vs. Localization: Anti-Immigrant and Hate Discourses in Italy," in Beyond M nopoly: Globalization and Contemporary Italian Media, ed. Michela Ardizzoni and Michela Ferrari (La ham, Lexington Books, 2009), 225-244.

33. Ibid.

34. Ibid.

35. Ibid.

36. Ibid.

37. Jennifer Guglielmo and Salvatore Salerno, Are Italians White? How Race is Made in America (New York: Routledge, 2003), 1-17.

38. Ibid.

39. Ibid.

40. Cere, "Globalization vs. Localization," 225-244; Guglielmo, Are Italians White? 1-17. 41. Cere, "Globaliz tion vs. Localization," 225-244.

42. Ibid.

43. Jones, "Fascist Movement," Macdonald, Mussolini and Italian Fascism.

44. Cere, "Globalization vs. Localization," 225-244.

45. Ibid.

46. Ibid.; Sabina Donati, “OO Migranti o Briganti”: Italian Emigration and Nationality Policies in the Peni sula," in A Political History of National Citizenship and Identity in Italy, 1861-1950 (Stanford: Stanford University Press, 2013), 95-117; Garau, "Northern League," 102-144; Richardson, "Continuity and Change,"180-202.

47. Cere, "Globalization vs. Localization,” 225-244; Donati, “O Migranti o Briganti', 95-117; Garau, "Northern League," 102-144; Richardson, "Continuity and Change," 180-202.

48. Cere, "Globalization vs. Localization," 225-244.

49. Lyttelton, Seizure of Power.

50. Cere, "Globalization vs. Localization," 225-244.

51. Edwards, "Tension in Florence."

52. Ibid.

53. Ibid.

54. Donati, “O Migranti o Briganti'” 95-117.

55. Ibid.

56. Ibid.

57. Fire at Sea, directed by Gianfranco Rosi (2016; Kino Lorber Inc., 2017), DVD.

58. Donati, “'O Migranti o Briganti',” 95-117.

59. Fire at Sea.

60. Ibid.

61. Ibid.

62. Cere, "Globalization vs. Localization,” 225-244; Donati, “O Migranti o Briganti,” 95-117; Garau, "Northern League," 102-144; Richardson, "Continuity and Change," 180-202.

63. Donati, “'O Migranti o Briganti,” 95-117.

64. Ibid.

65. Ibid.; Fire at Sea.

66. Fire at Sea.

67. Ibid.

68. Donati, “'O Migranti o Briganti'," 95-117.

69. Ibid.

70. Brighenti, “At the Wall, 315-332.

71. Sonja Plesset, Sheltering Women: Negotiating Gender and Violence in Northern Italy (Stanford: Stanford University Press, 2006).

72. Ibid.

73. Ibid.

74. Ibid.

75. Krizia Nardini, "Men's Anti-Violence Activism: The Case of Two Men's Networks in Contemporary Italy and Spain," Tijdschrift voor Genderstudies 16, no. 4 (2013): 41-53.

76. Ibid.

77. Ibid.

78. Ibid.

79. Ibid.; Roberto Pani and Samanta Sagliaschi, "Psychopathology of Excitatory and Compulsive A pects of Vandalistic Graffiti," Psychological Reports 105, no. 3 (2009): 1027-1038, https://doi.org/10.2466 pr0.105.f.1027-1038.

80. Mullins, "Everyday Timings of Dissent," 1-279. 
81. Ibid.; Andrea L. Hajek, "Bologna and the Trauma of March 1977: The Intellettuali Contro and their Resis ance to the Local Communist Party," Carte Italiane 2, no. 7 (2011): 81-100.

82. Hajek, "Bologna," 81-100; Mullins, "Everyday Timings of Dissent," 1-279.

83. Mullins, "Everyday Timings of Dissent," 1-279.

84. Hajek, "Bologna," 81-100; Mullins, "Everyday Timings of Dissent," 1-279.

85. Pani, "Psychopathology," 1027-1038.

86. Ibid.

87. Ibid.

88. Ibid.

89. Cere, "Globalization vs. Localization," 225-244.

90. Ibid.; Richardson, "Continuity and Change," 180-202.

91. Giovanni Depau, "How Graffiti Provide Evidence on the Relationship between Writing, Orality, and Ide tity," Writing Systems Research 4, no. 2 (2012): 185-194, https://doi.org/10.1080/17586801.2012.6581; Claire Speak, "Right-Wing Triumphs in Sardinia's Local Elections," The Local IT, February 29, 2019, www.thelocal.it/20190226/right-wing-triumphs-in-sardinias-local-elections.

92. Depau, "Graffiti," 185-194.

93. Lovata, Understanding Graffiti.

94. Depau, "Graffiti," 185-194.

95. Ibid.

96. Cere, "Globalization vs. Localization," 225-244.

97. Depau, "Graffiti," 185-194.

98. Cere, "Globalization vs. Localization," 225-244.

99. Depau, "Graffiti," 185-194.

100. Ibid.; Elisabetta Povoledo, "Francesco Cossiga Is Dead at 82; Led Italy and its Antiterrorism Battle," New York Times, August 17, 2010, https://www.nytimes.com/2010/08/18/world/europe/18cossiga.html.

101. Depau, "Graffiti," 185-194.

102. Ibid.; Povoledo, "Francesco Cossiga."

103. Depau, "Graffiti," 185-194.

104. Cere, "Globalization vs. Localization, 225-244.

105. Ibid.

106. Garau, "Northern League," 102-144.

107. Ibid.

108. La Rocca, "LGBTQ."

109. Paolo Heywood, "Agreeing to Disagree: LGBTQ Activism and the Church in Italy," HAU: Journal of Ethn graphic Theory 5, no. 2 (2015): 325-344; La Rocca, "LGBTQ."

110. La Rocca, "LGBTQ."

111. Heywood, "Agreeing to Disagree," 325-344. 